\title{
Development and Plasticity of Outer Retinal Circuitry Following Genetic Removal of Horizontal Cells
}

\author{
Patrick W. Keeley, ${ }^{1,2}$ Gabriel Luna, ${ }^{1,3}$ Robert N. Fariss, ${ }^{10}$ Kimberly A. Skyles, ${ }^{1}$ Nils R. Madsen, ${ }^{1}$ Mary A. Raven, ${ }^{1,2}$ \\ Ross A. Poché, ${ }^{6}$ Eric C. Swindell, ${ }^{8}$ Milan Jamrich, ${ }^{7}$ Edwin C. Oh, ${ }^{9}$ Anand Swaroop, ${ }^{11}$ Steven K. Fisher, ${ }^{1,2,4}$ \\ and Benjamin E. Reese ${ }^{1,5}$ \\ ${ }^{1}$ Neuroscience Research Institute, ${ }^{2}$ Department of Molecular, Cellular and Developmental Biology, ${ }^{3}$ Center for Bio-Image Informatics, ${ }^{4}$ Department of \\ Electrical and Computer Engineering, and ${ }^{5}$ Department of Psychological and Brain Sciences, University of California, Santa Barbara, California 93106, \\ ${ }^{6}$ Department of Molecular Physiology and Biophysics and ${ }^{7}$ Department of Molecular and Human Genetics, Baylor College of Medicine, Houston, Texas \\ 77030, ${ }^{8}$ Department of Pediatrics, University of Texas Medical School, Houston, Texas 77030, 9 Department of Medicine, Division of Neurology, Center for \\ Human Disease Modeling, Duke University Medical Center, Durham, North Carolina 27710, and ${ }^{10}$ Biological Imaging Core and ${ }^{11}$ Neurobiology- \\ Neurodegeneration and Repair Laboratory, National Eye Institute, National Institutes of Health, Bethesda, Maryland 20892
}

The present study examined the consequences of eliminating horizontal cells from the outer retina during embryogenesis upon the organization and assembly of the outer plexiform layer (OPL). Retinal horizontal cells exhibit a migration defect in Lim1-conditional knock-out (Lim1-CKO) mice and become mispositioned in the inner retina before birth, redirecting their dendrites into the inner plexiform layer. The resultant (mature) OPL, developing in the absence of horizontal cells, shows a retraction of rod spherules into the outer nuclear layer and a sprouting of rod bipolar cell dendrites to reach ectopic ribbon-protein puncta. Cone pedicles and the dendrites of type 7 cone bipolar cells retain their characteristic stratification and colocalization within the collapsed OPL, although both are atrophic and the spatial distribution of the pedicles is disrupted. Developmental analysis of Lim 1-CKO retina reveals that components of the rod and cone pathways initially co-assemble within their normal strata in the OPL, indicating that horizontal cells are not required for the correct targeting of photoreceptor terminals or bipolar cell dendrites. As the rod spherules begin to retract during the second postnatal week, rod bipolar cells initially show no signs of ectopic growth, sprouting only subsequently and continuing to do so well after the eighth postnatal week. These results demonstrate the critical yet distinctive roles for horizontal cells on the rod and cone pathways and highlight a unique and as-yet-unrecognized maintenance function of an inhibitory interneuron that is not required for the initial targeting and co-stratification of other components in the circuit.

\section{Introduction}

Nerve cells communicate by way of synaptic connections that are established during early development as presynaptic and postsynaptic partners identify one another during their periods of differentiation. The retina is a particularly attractive model for studying such developmental interactions because these synaptic connections are positioned in distinct locations within the retinal architecture in one of two different plexiform layers. Within the inner plexiform layer (IPL), different populations of bipolar, amacrine and ganglion cells are interconnected in discrete sub-

Received April 1, 2013; revised Sept. 16, 2013; accepted 0ct. 7, 2013.

Author contributions: P.W.K., M.A.R., R.A.P., and B.E.R. designed research; P.W.K., G.L., R.F., and E.C.O. performed research; E.C.S., M.J., E.C.O., and A.S. contributed unpublished reagents/analytic tools; P.W.K., K.A.S., N.R.M., and B.E.R. analyzed data; P.W.K., R.F., A.S., S.K.F., and B.E.R. wrote the paper.

This research was supported by the National Institutes of Health (Grant R01 EY-019968 and Grant S10 RR-022585 to B.E.R.; Grant S10 OD-010610 to M.A.R.), the National Science Foundation (Grants 0IA-0941717 and IIS-0808772 to S.K.F.), and the National Eye Institute Intramural Research Program (A.S.) and was facilitated by the Neuroscience Research Institute/Department of Molecular, Cellular, and Developmental Biology Microscopy Facility at University of California, Santa Barbara. We thank Dr. Richard Behringer for providing initial Lim1-flox mice for breeding.

Correspondence should be addressed to B.E. Reese, Neuroscience Research Institute, University of California, Santa Barbara, CA 93106-5060. E-mail: breese@psych.ucsb.edu.

DOI:10.1523/JNEUROSCI.1373-13.2013

Copyright $\odot 2013$ the authors $\quad 0270-6474 / 13 / 3317847-16 \$ 15.00 / 0$ layers, and the specificity of these connections is thought to be mediated by the expression of spatially restricted guidance cue proteins (Matsuoka et al., 2011a, 2011b) and unique celladhesion molecules on the different presynaptic and postsynaptic cell-types (Yamagata and Sanes, 2008, 2012; Fuerst et al., 2009; Huberman et al., 2010). Within the outer plexiform layer (OPL), the rod photoreceptors innervate rod bipolar cells and the axon terminals of horizontal cells and the cone photoreceptors innervate several types of cone bipolar cells and the dendritic arbors of horizontal cells. Less is known about the factors that are responsible for connectivity between these cell types within the outer retina, although the horizontal cells have been shown recently to use guidance proteins, suggesting that similar mechanisms may regulate the development of both plexiform layers (Matsuoka et al., 2012). Unlike the IPL, however, the contributors to the OPL exhibit a great degree of plasticity even later in life, after the mature patterns of stratification and connectivity are established (Fisher et al., 2005).

The present study investigated the role of horizontal cells in the development and maintenance of the OPL using a genetic approach by eliminating these cells from the outer retina. Specifically, we used a conditional knock-out approach to delete the 
Table 1. List of primary antibodies, immunogen, source, and working dilution

\begin{tabular}{|c|c|c|c|c|c|}
\hline Antigen & Abbreviation & Immunogen & Type & Supplier & Dilution \\
\hline Calbindin & Calb & Purified calbindin D-28K protein from chicken gut & Mouse monoclonal & Sigma C-8666 & $1: 10,000$ \\
\hline Calbindin & Calb & Purified calbindin D-28K protein from bovine cerebellum & Rabbit polyclonal & Calbiochem PC253L & $1: 10,000$ \\
\hline Neurofilament 150kD & NF150 & Highly purified bovine neurofilament-150K polypeptide & Rabbit polyclonal & Chemicon AB1981 & $1: 10,000$ \\
\hline C-terminal Binding Protein 2 & $\mathrm{CtBP2}$ & $\begin{array}{l}\text { Synthetic polypeptide corresponding to AA361-AA445 of } \\
\text { mouse CtBP2 }\end{array}$ & Mouse monoclonal & BD Transduction Laboratories 612044 & 1:500 \\
\hline Receptor Accessory Protein 6 & Reep6 & $\begin{array}{l}\text { Synthetic polypeptides: CSTSEPPAALELDP and } \\
\text { MDGLRQRFERFLEQKNC }\end{array}$ & Rabbit polyclonal & Custom generated (see text) & $1: 1000$ \\
\hline Mouse Cone Arrestin & $\mathrm{mCAR}$ & Synthetic linear peptide & Rabbit polyclonal & Millipore AB15282 & $1: 10,000$ \\
\hline Postsynaptic Density 95 & PSD-95 & Purified recombinant rat PSD-95 & Mouse monoclonal & Thermo Scientific MA1-045 & $1: 250$ \\
\hline Protein Kinase C & PKC & $\begin{array}{l}\text { Synthetic polypeptide: CYVNPQFVHPILQSAV coupled to } \\
\text { carrier protein }\end{array}$ & Rabbit polyclonal & Cambio CA-1042 & $1: 10,000$ \\
\hline Cytochrome 0xidase & $\mathrm{CO}$ & $\begin{array}{l}\text { OxPhos IV complexes isolated from bovine heart, bovine } \\
\text { liver, and human heart }\end{array}$ & Mouse monoclonal & Invitrogen A6403 & $1: 100$ \\
\hline Synaptotagmin 2 & Syt2 & Homogenized whole zebrafish (Trevarrow et al., 1990) & Mouse monoclonal & $\begin{array}{l}\text { Zebrafish International Resource } \\
\text { Center }\end{array}$ & 1:100 \\
\hline Red/Green Cone Opsin & None & Recombinant human red/green opsin & Rabbit polyclonal & Millipore AB5405 & $1: 1000$ \\
\hline Blue Cone 0psin & None & Recombinant human blue opsin & Rabbit polyclonal & Millipore AB5407 & $1: 1000$ \\
\hline
\end{tabular}

LIM homeobox protein 1 transcription factor ( $\operatorname{Lim} 1$ hereafter) in the mouse retina. Expressed solely in horizontal cells, Lim1 is required for the proper migration of these inhibitory interneurons and removal of the gene causes them to become misplaced to the inner retina during the later stages of embryogenesis, before formation of the OPL (Poché et al., 2007). Because these ectopically positioned horizontal cells fail to differentiate processes into the OPL, we assessed the developmental consequences of horizontal cell depletion from the OPL upon photoreceptor and bipolar cell differentiation. We demonstrate that horizontal cells are not required for the initial targeting and stratification of the remaining OPL components. Horizontal cells are critical, however, for the maintenance of normal photoreceptor-bipolar cell connectivity, although different aspects of each circuit are disrupted in their absence, with dendritic atrophy observed in the cone pathway versus spherule retraction and dendritic sprouting in the rod pathway.

\section{Materials and Methods}

Animals. Lim $1^{\text {flox / flox }}$ mice, in which the endogenous Lim 1 coding region is flanked by LoxP sites (Kwan and Behringer, 2002), were crossed with $R x$-Cre mice, in which the expression of cre recombinase is driven by regulatory elements of $R x$ (Swindell et al., 2006) to create retina-specific Lim1 conditional knock-out (CKO) mice. Some CKO mice were crossed with Gust-GFP mice, in which an $8.4 \mathrm{~kb}$ upstream segment of $\alpha$-gustducin drives the expression of GFP (Huang et al., 2003), to visualize type 7 cone bipolars and rod bipolar cells for DiI-labeling. Mice of either sex were used in this study and all animals were euthanized in accordance with the National Institutes of Health Guide for the Care and Use of Laboratory Animals and under local authorization from the Institutional Animal Care and Use Committee at the University of California, Santa Barbara.

Immunofluorescence and antibody characterization. Mice were deeply anesthetized with a lethal dose of Euthasol $(120 \mathrm{mg} / \mathrm{kg}$, i.p.; Virbac) and intracardially perfused for $15 \mathrm{~min}$ with $0.9 \% \mathrm{NaCl}$ in water followed by $4 \%$ paraformaldehyde (PFA) dissolved in $0.1 \mathrm{~m}$ sodium phosphate, $\mathrm{pH}$ 7.2 , at $20^{\circ} \mathrm{C}$. Eyes were removed and immersion fixed in $4 \%$ PFA for an additional $15 \mathrm{~min}$ and then retinas were dissected out and prepared as whole mounts or embedded in $5 \%$ agarose for sectioning at $150 \mu \mathrm{m}$ on a Vibratome. Retinas were processed for immunofluorescence according to the following protocol: tissue was incubated in 5\% normal donkey serum for $3 \mathrm{~h}$, followed by a mixture of primary antibodies for $3 \mathrm{~d}$, and then secondary antibodies overnight. All incubation solutions were diluted in $0.1 \mathrm{~m}$ sodium phosphate, $\mathrm{pH} 7.2$, containing $1 \%$ Triton $\mathrm{X}-100$ and $0.9 \% \mathrm{NaCl}$ and, between each incubation step, tissue was rinsed in

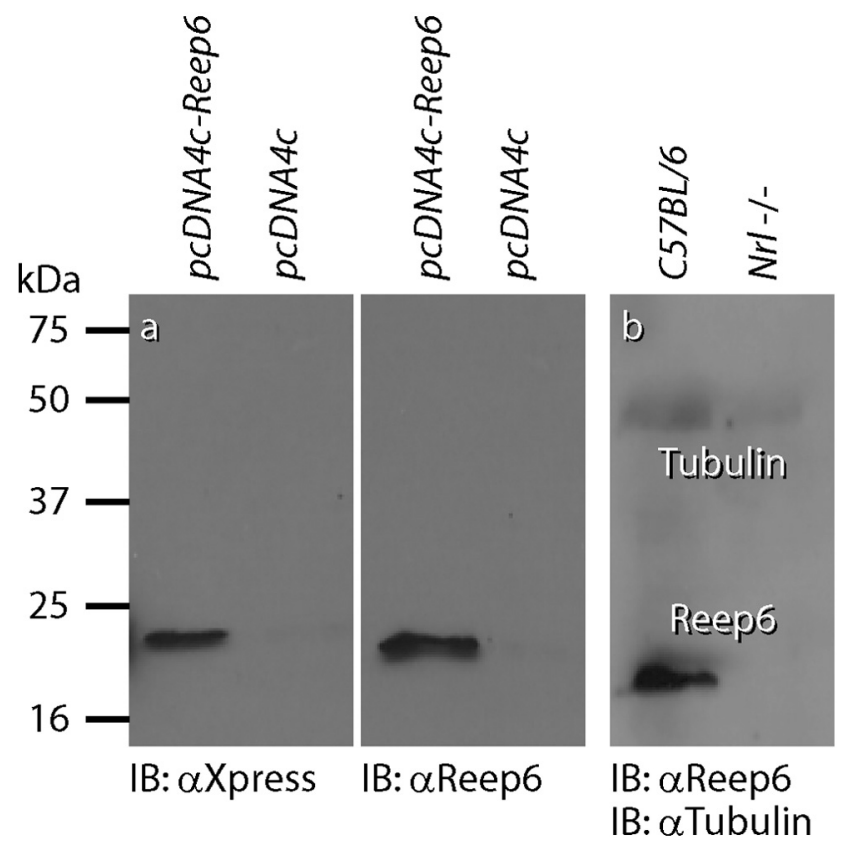

Figure 1. Characterization of Reep6 antibody. HEK293T cells were transfected with pcDNA4c vector or pcDNA4c construct containing mouse Reep6 fused to an Xpress-tag. Protein expression was analyzed by immunoblotting (IB) using anti-Xpress or anti-Reep6 antiserum (a). Protein extracts from (57BL/6 and $\mathrm{Nrl}^{-1-}$ mouse retinas were analyzed using Reep6 antibody (b).

PBS three times for $10 \mathrm{~min}$. All steps were performed at $4^{\circ} \mathrm{C}$ with gentle agitation.

Table 1 lists all primary antibodies used in this study, along with the abbreviation, immunogen, type, supplier, and working dilution for each. We generated a rabbit polyclonal antibody against two peptides corresponding to mouse Reep6 protein (CSTSEPPAALELDPK and MDGLRQRFERFLEQKNC); this antibody recognized an $\sim 20 \mathrm{kDa}$ protein in HEK293T cells transfected with full-length Xpress-tagged Reep6 (Fig. 1a). Given the rod photoreceptor-specific expression of Reep6 in the retina, antibody specificity was determined by probing retinal extracts from C57BL/6 and cone-only $\mathrm{Nrl}^{-1-}$ mice (Mears et al., 2001; Fig. 1b). Donkey antimouse and anti-rabbit IgGs conjugated to fluorescent Alexa Fluor dyes (A21202, A21203, A21206, and A21207, 1:200; Invitrogen) were used to detect the primary antibodies. The lectin peanut agglutinin (PNA) conjugated to the fluorescent dye Alexa Fluor 647 (L32460, 1:1000; Invitrogen) was used to label cone pedicle active sites and NeuroTrace 530/615 (N21482, 1:250; Invitrogen), a fluorescent Nissl stain, was used to label the 
nuclear layers of the retina. When used, these were added to the mixture of primary antibodies. All tissue was imaged on an Olympus Fluoview 1000 laser scanning confocal microscope using a $25 \times$ water-immersion lens with a numerical aperture of 1.05 or a $40 \times$ oil-immersion lens with a numerical aperture of 1.30 (Olympus). Negative control sections were routinely processed through the identical staining protocol except that the mixture of primary antibodies was replaced with $1 \%$ Triton X-100 in PBS.

DiI labeling. Eyes from wild-type and CKO mice harboring the GustGFP transgene were removed from deeply anesthetized mice, the cornea and lens were dissected out, and eyecups were immersion-fixed in $4 \%$ PFA dissolved in $0.1 \mathrm{M}$ sodium phosphate, $\mathrm{pH} 7.2$, at $20^{\circ} \mathrm{C}$ for $30 \mathrm{~min}$. Retinas were isolated as whole mounts or sectioned on a Vibratome and transferred to a fixed-stage fluorescent microscope with a $60 \times$ water dipping lens (Nikon). A borosilicate glass micropipette with a tip diameter of $\sim 0.5 \mu \mathrm{m}$ was backfilled with a solution of the lipophilic dye CM-DiI (V22888; Invitrogen) and fastened to a micromanipulator (Burleigh). Single GFP-positive axon terminals of either rod bipolar cells or type 7 cone bipolar cells were targeted for microinjection, as described previously (Keeley and Reese, 2010). CM-DiI was expelled from the pipette tip using positive current until a bolus of dye was clearly visible at the depth of axon stratification. Retinas were subsequently labeled with PNA overnight at room temperature (1:250) and imaged using a Fluoview1000 confocal microscope, as above.

Image processing and analysis. All metrics were collected using the image processing software MetaMorph (version 7.5.6.0; Molecular Devices) from the original confocal image stacks. Images were prepared by creating maximum projection images using MetaMorph, which were subsequently pseudocolored and contrast enhanced using the "levels" tool in Photoshop CS3 (Adobe Systems).

Several measurements were taken for each DiI-labeled bipolar cell. Dendritic area was determined by creating a convex polygon around the entire dendritic arbor and somal area was determined by tracing the outline of the cell body at its widest extent. In addition, the number of terminal dendritic branches was quantified for each cell by following individual dendrites through the depth of the OPL using the individual $Z$-stack images, which were taken at $0.5 \mu \mathrm{m}$ steps. Examples of cone and rod bipolar cell quantification using these procedures have been described previously (Figs. 2, 7, respectively, in Keeley and Reese, 2010).

Cone pedicles were analyzed in whole-mount preparations stained for both cone arrestin and PNA. Three retinas from each genotype were used: two central and two peripheral fields were imaged for each control retina and four central and four peripheral fields were imaged for each CKO retina. Each field was $0.01 \mathrm{~mm}^{2}$ in area. Pedicle area and active site area were obtained by forming a convex polygon around individual cone arrestin-positive pedicles and around all PNA puncta that fell within the pedicle boundary, respectively. For each field, the coefficient of variation (CoV) was determined for both pedicle area and active site area by dividing the SD by the mean. In addition, the centroid of each cone pedicle within a field was determined and the resulting $\mathrm{X}-\mathrm{Y}$ coordinates were used to define the Voronoi domains associated with each pedicle using a customized spatial statistics program developed in MATLAB (MathWorks), as described previously (Keeley et al., 2012).

To analyze the relationship between horizontal cells and rod bipolar dendritic sprout density, confocal $Z$-stacks were taken of whole-mount preparations stained for PKC and calbindin or NF150. The boundary between of the OPL and outer nuclear layer (ONL) was determined for each image stack by finding the plane in which either calbindin or NF150 staining was completely absent. To display the population of horizontal cells, maximum projection images were created of either the calbindin or the NF150 channel from the inner nuclear layer (INL) to the OPL/ONL boundary. To display the ectopic rod bipolar cell dendrites, maximum projection images were created of the PKC channel from the OPL/ONL boundary to $\sim 40 \mu \mathrm{m}$ into the ONL.

Total cell type estimates in aged retinas were determined by calculating an average density across several sample sites and multiplying by retinal area. Average densities for rod bipolar cells and type 2 cone bipolar cells were calculated by counting the number of PKC-positive somata and
Syt2-positive axons, respectively, in four central and four peripheral fields $0.1 \mathrm{~mm}^{2}$ in area. Average densities for rods were determined by counting photoreceptor inner segments using a $60 \times$ oil-immersion lens on a Microphot FXA fluorescence photomicroscope equipped for differential interference contrast (DIC) optics (Nikon) and then subtracting the number of PNA-positive cone outer segments labeled within the same field. Cone densities were determined by counting cone opsinpositive outer segments using a mixture of UV- and M-opsin antibodies. Then, $225 \mu \mathrm{m}^{2}$ fields for rods and 10,000 $\mu \mathrm{m}^{2}$ fields for cones were chosen at $1 \mathrm{~mm}$ intervals across the entire retinal surface in a square grid, with a minimum of 13 fields sampled per retina. DIC images of photoreceptors were contrast-enhanced using the "unsharp mask" filter tool in Photoshop.

Electron microscopy. Mice at 2 months of age were deeply anesthetized with a lethal dose of Euthasol (120 mg/kg, i.p.; Virbac) and intracardially perfused for 15 min with $\sim 2 \mathrm{ml}$ of $0.9 \% \mathrm{NaCl}$ in water, followed by a mixture of $2 \%$ paraformaldehyde: $2 \%$ glutaraldehyde dissolved in $0.1 \mathrm{M}$ sodium phosphate, $\mathrm{pH} 7.2$, at $20^{\circ} \mathrm{C}$. Eyes and surrounding extraocular tissues were dissected and immersed in the same fixative for a further $48 \mathrm{~h}$. The protocol for preparing tissues for serial block-face scanning electron microscopy was modified from protocol version 7-01-2010 developed by Deerinck et al. (National Center for Microscopy and Imaging Research, University of California-San Diego). Before processing, eyes were rinsed on ice in $0.15 \mathrm{~m}$ cacodylate buffer containing $2 \mathrm{~mm}$ calcium chloride, and then secondarily fixed in $2.5 \%$ paraformaldehyde and $2.5 \%$ glutaraldehyde in $0.1 \mathrm{~m}$ sodium cacodylate buffer, $\mathrm{pH} 7.4$ (EM Sciences) for $24 \mathrm{~h}$. Eyes were washed $5 \times 3 \mathrm{~min}$ in $0.15 \mathrm{~m}$ cacodylate buffer containing $2 \mathrm{~mm}$ calcium. Eyes were then incubated in a freshly prepared solution containing $3 \%$ potassium ferrocyanide (Fisher Scientific) in 0.3 M cacodylate buffer, with $4 \mathrm{~mm}$ calcium chloride, combined with an equal volume of $4 \%$ aqueous osmium tetroxide (EM Sciences), and added immediately to the tissue for $1 \mathrm{~h}$ on ice. Eyes were washed in doubledistilled water $\left(\mathrm{ddH}_{2} \mathrm{O}\right)$, transferred to filtered $1 \%$ thiocarbohydrazide (EM Sciences) for $20 \mathrm{~min}$ at $20^{\circ} \mathrm{C}$, washed again $5 \times 3 \mathrm{~min}$ in $\mathrm{ddH}_{2} \mathrm{O}$, and then transferred to $2 \%$ osmium tetroxide for $30 \mathrm{~min}$ at room temperature. Eyes were washed in $\mathrm{ddH} 2 \mathrm{O}$ and transferred to $1 \%$ uranyl acetate overnight at $4^{\circ} \mathrm{C}$. The following day, eyes were washed in $\mathrm{ddH} 2 \mathrm{O}$ and incubated in a lead aspartate solution $(0.066 \mathrm{~g}$ of lead nitrate; EM Sciences), dissolved in $10 \mathrm{ml}$ of $0.03 \mathrm{M}$ aspartic acid solution, $\mathrm{pH}$ adjusted to 5.5 with $1 \mathrm{~N} \mathrm{KOH}$ in a $60^{\circ} \mathrm{C}$ oven for $30 \mathrm{~min}$. The tissue was rinsed $5 \times 3$ min in $\mathrm{H}_{2} \mathrm{O}$ and then dehydrated through graded alcohols into propylene oxide. Eyes were allowed to infiltrate in a 1:1 mixture of propylene oxide and Embed 812 (EM Sciences) on a rotator for $24 \mathrm{~h}$ and then embedded in pure Embed 812 and polymerized at $60^{\circ} \mathrm{C}$ for $48 \mathrm{~h}$.

Blocks were trimmed and mounted on aluminum specimen pins ( $\mathrm{Ga}-$ $\tan$ ) using a conductive epoxy (ITW Chemtronics) that was polymerized at $90^{\circ} \mathrm{C}$ for $12 \mathrm{~h}$. Specimens were transferred to the 3View ultramicrotome unit (Gatan) operating on a SIGMA field emission scanning electron microscope (Zeiss) and sections were cut from the block face at $50 \mathrm{~nm}$, imaging every section at a resolution of $26 \mathrm{~nm}$ per pixel. 3D reconstructions were generated using IMOD software (Kremer et al.,1996).

Statistics. All comparisons between Lim1-WT and Lim1-CKO conditions were tested for statistical significance $(p<0.05$, indicated by an asterisk in the figures) using Student's two-tailed $t$ tests.

\section{Results}

\section{The OPL of the Lim 1-CKO retina is depleted of horizontal cell processes}

Compared with the cytoarchitecture of wild-type retinas, Lim1CKO retinas displayed a marked reduction in the thickness of the OPL in maturity, at 2 months of age (Fig. $2 a, a^{\prime}, e, e^{\prime}$, red arrows), as described previously (Poché et al., 2007). Some regions of the Lim1-CKO retina lacked a cell-free plexiform layer altogether and the somata of the ONL were found to abut those residing in the INL (Fig. $2 a^{\prime}, e^{\prime}$ ). Neurofilament-150 (NF150) labeling, which is normally present in horizontal cell axons (Fig. 2b), was often absent in the OPL of the Lim1-CKO retinas (Fig. 2b'), 


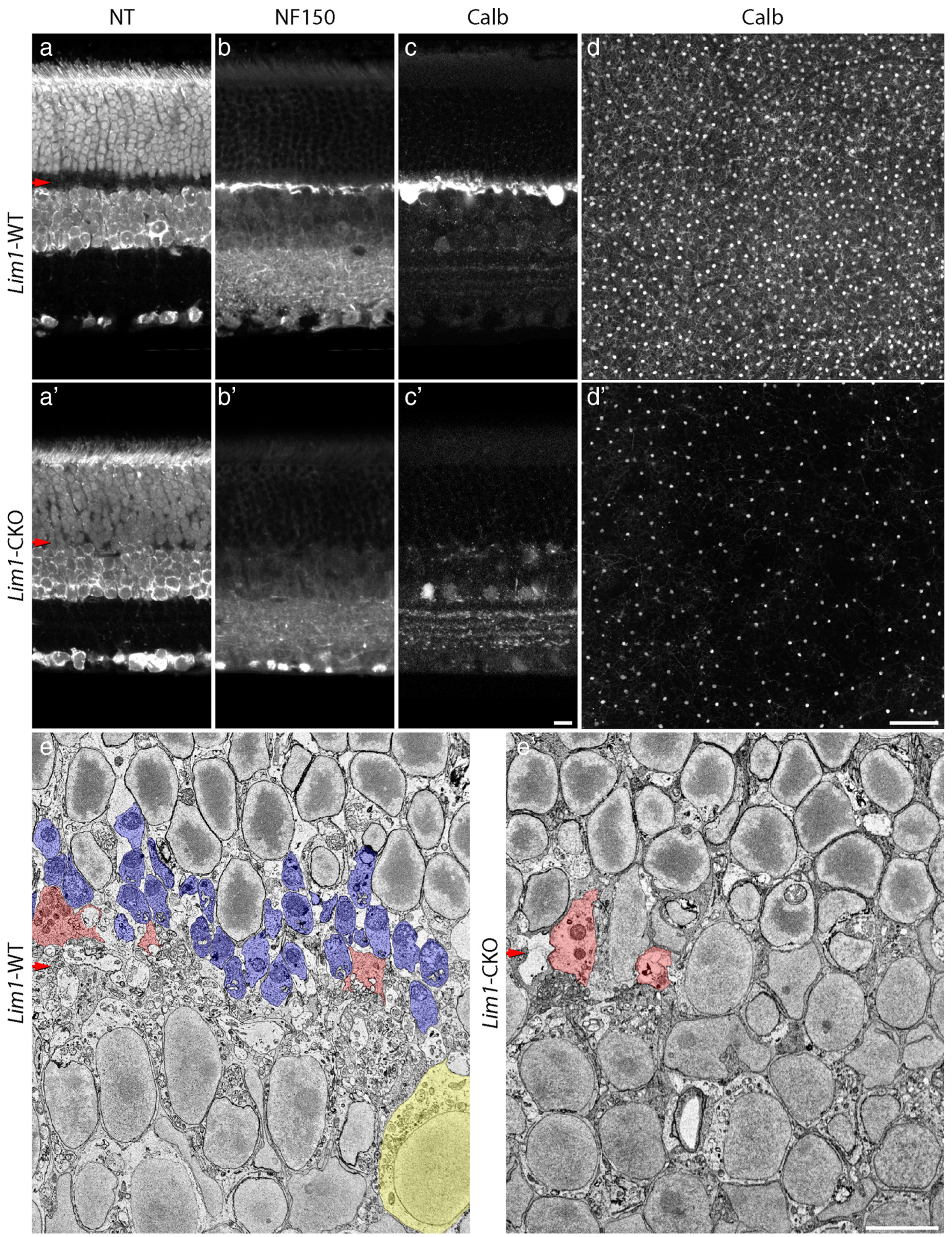

Figure 2. Early removal of horizontal cells yields a collapsed OPL. The Lim 1-CKO retina at 2 months of age lacks a cell-sparse OPL, as evidenced by staining for NeuroTrace (NT; $\boldsymbol{a}, \boldsymbol{a}^{\prime}$ ). As expected from previous accounts, horizontal cells and their processes, labeled for either neurofilaments (NT150) or calbindin (Calb), are missing from the OPL (b, $\left.\boldsymbol{b}^{\prime}, \boldsymbol{c}, \boldsymbol{c}^{\prime}\right)$. Whole-mounted retinas labeled for Calb at 5 months of age showed a substantial reduction in horizontal cell density across large regions of retina $\left(\boldsymbol{d}, \boldsymbol{d}^{\prime}\right)$. Thin sections at 2 months of age confirmed the lack of an OPL $\left(\boldsymbol{e}, \boldsymbol{e}^{\prime}\right)$. The boundary between the ONL and INL can be discriminated by the characteristic heterochromatin of the rod nuclei in the top half $\left(\boldsymbol{e}^{\prime}\right)$. A single horizontal cell (yellow) is shown to the right side of the control INL $(\boldsymbol{e})$, and numerous rod spherules (blue), identified by the presence of single large mitochondria and/or the presence of invaginating processes, are present across the OPL (e) whereas none are present within the Lim1-CKO retina ( $\left.\boldsymbol{e}^{\prime}\right)$; cone pedicles (pink), however, are present in both. Scale bars: $\boldsymbol{a}-\boldsymbol{c}$ $e, 10 \mu \mathrm{m} ; \boldsymbol{d}, 100 \mu \mathrm{m}$. The horizontal red arrows indicate the position of the OPL in this and subsequent figures. 
whereas characteristic expression of NF150 in the IPL was maintained. Immunolabeling for calbindin, a calcium-binding protein found in horizontal cell dendrites and somata (Fig. 2c), revealed a coincident reduction in the horizontal cell dendritic plexus in these same regions of the CKO retina (Fig. $2 c^{\prime}$ ). Overall, we achieved a greater depletion of the population of horizontal cells from the outer retina by using a more extensive creexpressing mouse, $R x$-cre (Swindell et al., 2006), relative to our previous studies using either Six3-cre or Chx10-cre (Poché et al., 2008 ), of a magnitude approaching $65 \%$ in some regions (Fig. $\left.2 d, d^{\prime}\right)$. Nevertheless, even using $R x$-cre, the depletion exhibited mosaicism across the retina due to incomplete recombination in the entire population of horizontal cells (Fig. $2 d^{\prime}$ ), as described previously (Poché et al., 2007). Although the local early depletion of horizontal cells in those previous studies was shown to yield a compensatory increase in the dendritic field sizes of neighboring (Lim1-intact, normally positioned) horizontal cells (Poché et al., 2008), the present results using $R x$-cre, yielding larger regions devoid of horizontal cells and their processes, must indicate there is an upper limit upon dendritic growth even when horizontal cells are freed from such homotypic constraints.

\section{The OPL shows a loss of presynaptic terminals and synaptic ribbons}

A clear reduction in the density of photoreceptor ribbons coincided with the collapse of the OPL, evidenced by immunolabeling for C-terminal calcium binding protein 2 (CtBP2; Fig. $\left.3 a, a^{\prime}\right)$. The majority of these missing ribbons were associated with the loss of spherules of the rod photoreceptors, as shown by the large decline of receptor accessory protein 6 (Reep6) labeling of the rod spherules (a rod-specific protein in the retina; H. Hao, S. Veleri, B. Sun, D. S. Kim, P.W.K., R. Sood, S. H. Manjunath, P. Liu, B.E.R., and A.S., manuscript in preparation; Fig. $\left.3 b, b^{\prime}\right)$, as well as by the conspicuous elimination of the population of structurally identified spherules in thin sections (Fig. $2 e, e^{\prime}$, blue). In contrast, cone terminals as labeled by mouse cone arrestin (mCAR) remained intact within the OPL (Fig. $3 c, c^{\prime}$ ) and contained ribbons within them, as CtBP2 labeling was found juxtaposed with PNA labeling (Fig. $3 f, f^{\prime}$ ), the latter being a selective marker for the invaginating synaptic regions of the cone pedicles ("active sites" hereafter) within the OPL (Fig. 3g, $g^{\prime}$; Blanks and Johnson, 1983; Haverkamp et al., 2001). The loss of the rod spherules from the OPL, evidenced by either Reep6 labeling or by their ultrastructural identification (Figs. $3 b^{\prime}, 2 e^{\prime}$ ), was not a consequence of widespread loss of the rod photoreceptor population itself because the thickness of the ONL was comparable and the outer segment layer was not atrophic (Fig. 3b, $b^{\prime}$ ) and the number of rod photoreceptors was not significantly reduced even as late as 7 months of age (see Fig. $\left.9 a, a^{\prime}, b\right)$. Indeed, the pattern of cytochrome oxidase staining within the ONL was not altered (Fig. $\left.3 j, j^{\prime}\right)$, suggesting an absence of cellular stress presaging cell death that has been observed in other models of retinal degeneration (Raven et al., 2008).

\section{Rod photoreceptor terminals retract into the ONL}

The ONL of the Lim1-CKO retina at 2 months of age frequently showed ectopic ribbon labeling overlying regions of retina displaying a collapsed OPL (Fig. $3 a^{\prime}$, diagonal arrowheads). Such CtBP2 puncta were never detected in the ONL of control retinas (compare Fig. $3 a$ ). The presence of these ectopically situated CtBP2 profiles, coupled with the absence of Reep6-positive spherules in the OPL, suggests that rod spher- ules have retracted into the ONL. Consistent with this interpretation, labeling for postsynaptic density-95 (PSD-95), a scaffolding protein normally present in both rod spherules and cone pedicles (Fig. $3 d$ ), revealed a substantial depletion from the OPL (Fig. $3 d^{\prime}$ ). This reduction coincided with an increase in ectopic PSD-95 immunoreactivity in the ONL that was never seen in wild-type retinas (Fig. $3 d^{\prime}$, arrowheads). Ectopic PSD-95-positive profiles in the ONL of the Lim1-CKO retina were not associated with any PNA labeling, whereas those remaining in the OPL typically coincided with PNA (Fig. $\left.3 h, h^{\prime}\right)$, suggesting that all of the misplaced PSD-95-positive profiles in the ONL (Fig. $3 d^{\prime}$ ) were associated with rod photoreceptors that had retracted their spherules. There was also an accumulation of PSD-95 labeling at the outer limiting membrane (Fig. $3 d^{\prime}$ ), suggesting substantial reorganization of the rod photoreceptors themselves. Consistent with this interpretation for a structural retraction of the rod spherule, $3 \mathrm{D}$ serial reconstructions confirmed that rod cells lacked any terminal extending beyond the soma itself (compare Fig. $3 k^{\prime}$, blue profiles, Fig. $3 k$, normal rod spherule). Whereas spherules in control retinas showed normal presence of a single large mitochondrion, a ribbon, a pair of horizontal processes extending deeper into the invagination (yellow and cyan processes), and another pair of invaginating rod bipolar processes beneath them (Fig. $3 k$, green and pink processes), the vitrealmost extension of four reconstructed rod photoreceptors was little more than the soma itself, with no obvious mitochondria, ribbons, or invaginations (Fig. $3 k^{\prime}$, blue profiles). Clearly, the loss of Reep6 labeling within the OPL of the Lim 1CKO retina (along with the reduction in CtBP2, PSD-95, and $\mathrm{CO})$ accurately reflects the structural retraction of rod spherules.

\section{Rod bipolar cell dendrites sprout into the ONL}

Coincident with this massive retraction of rod photoreceptor terminals by $\mathrm{P} 60$, the population of rod bipolar cells sprouted dendrites into the ONL, as evidenced by the presence of PKC-positive processes ascending beyond the level of the collapsed OPL (compare Fig. $3 e^{\prime}$, diagonal arrows, Fig. 3e). Indeed, the tips of many of these dendritic profiles were juxtaposed to ectopic CtBP2positive profiles (Fig. $3 i, i^{\prime}$ ), although we could not identify these unambiguously in our ultrastructural analysis. In one instance, two processes arising from distinct rod bipolar dendrites were found to invaginate into a slight cytoplasmic extension of the soma, yet no well defined ribbon-like organelle could be observed presynaptic to these processes (Fig. $3 l^{\prime}$ ). To examine the morphology of the dendritic arbors of these sprouted rod bipolar cells in greater detail, single cells were labeled by the local application of DiI to their axonal terminals (Keeley and Reese, 2010). As in control retinas, dendrites of single rod bipolar cells in the Lim1CKO retina bypassed the PNA-positive pedicles (Fig. 4a, $a^{\prime}$ ). However, although those in control retinas gave rise to a spray of dendritic terminals confined to the OPL (Fig. $4 f$ ), the dendrites of single rod bipolar cells in Lim1-CKO retinas extended as thick stalks into the ONL, branching progressively at greater distances from the soma (Fig. $4 f^{\prime}$ ). The distribution of this sprouting was inversely related to the presence of normally positioned horizontal cells and their processes remaining in the Lim1-CKO at P60, which was readily seen in whole-mount preparations labeled for PKC and calbindin or NF150. The density of PKC-positive sprouts in the ONL (red) was increased in regions lacking calbindin or NF150 labeling in the INL and OPL (cyan) of the Lim1- 


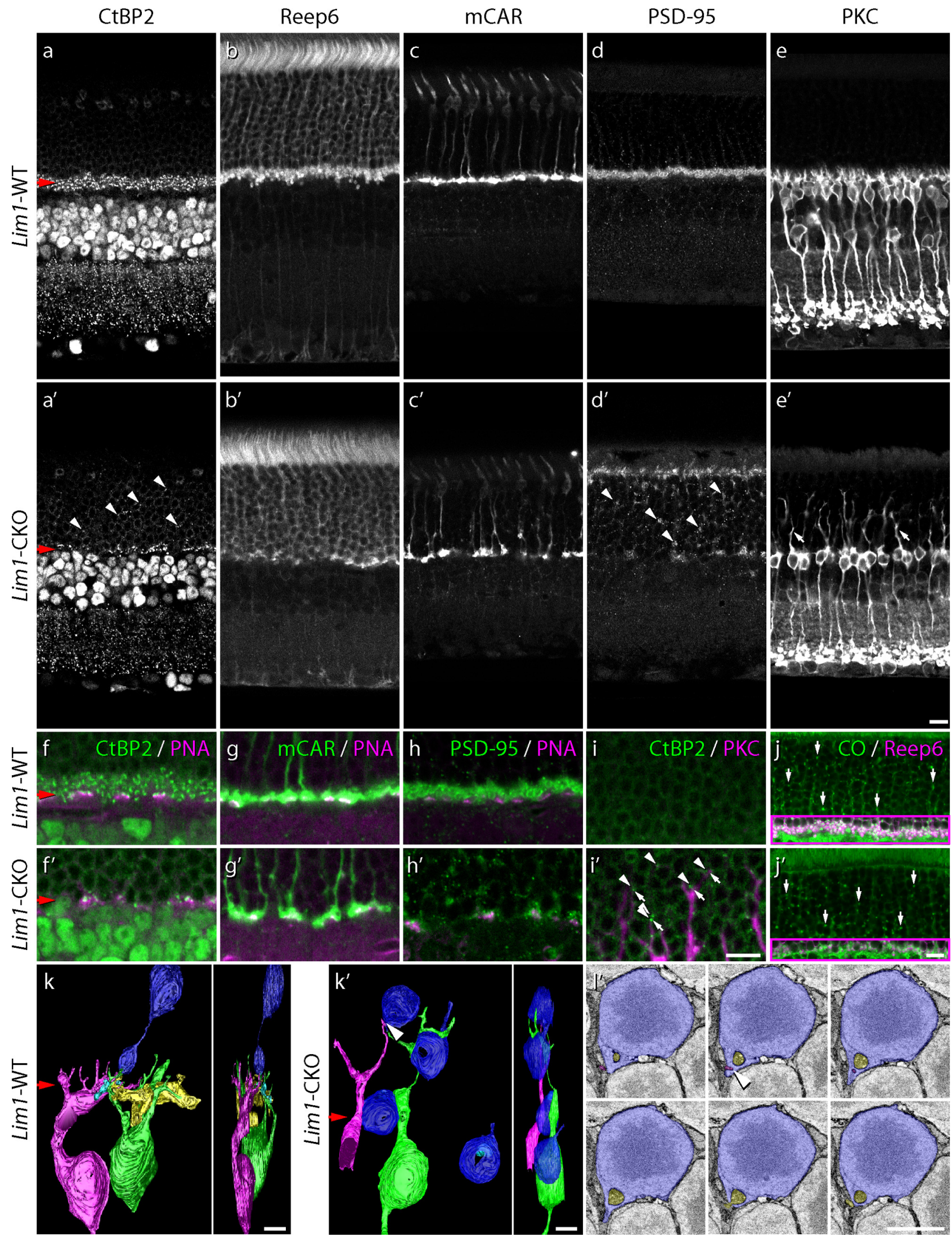

Figure 3. Early horizontal cell loss alters the architecture of the OPL. The layer of CtBP2-positive synaptic ribbons normally present within the photoreceptor terminals is substantially depleted in the Lim1-CKO retina $\left(\boldsymbol{a}, \boldsymbol{a}^{\prime}\right)$ due to the elimination of the rod spherules, labeled for Reep6, from this stratum $\left(\boldsymbol{b}, \boldsymbol{b}^{\prime}\right)$. Cone pedicle stratification is not affected, as evidenced by the retention of mCAR-positive profiles at the remaining ONL/INL border $\left(\boldsymbol{c}, \boldsymbol{c}^{\prime}\right)$; however, PNA-labeled active sites at these pedicles appeared atrophic $\left(\boldsymbol{f}, \boldsymbol{f}^{\prime}\right)$. Pedicles still contain synaptic ribbons, shown by the juxtaposition of (tBP2-positive puncta with PNA-positive active sites at the cone pedicles $\left(\boldsymbol{f}, \boldsymbol{f}^{\prime}\right)$, the PNA still being exclusively associated with mCAR-positive pedicles $\left(\boldsymbol{g}, \boldsymbol{g}^{\prime}\right)$. Rod spherules have retracted into the $0 \mathrm{NL}$, as evidenced by the presence of synaptic ribbon puncta in this layer ( $\boldsymbol{a}^{\prime}$, diagonal arrowheads) and by the redistribution of PSD-95 (Figure legend continues.) 


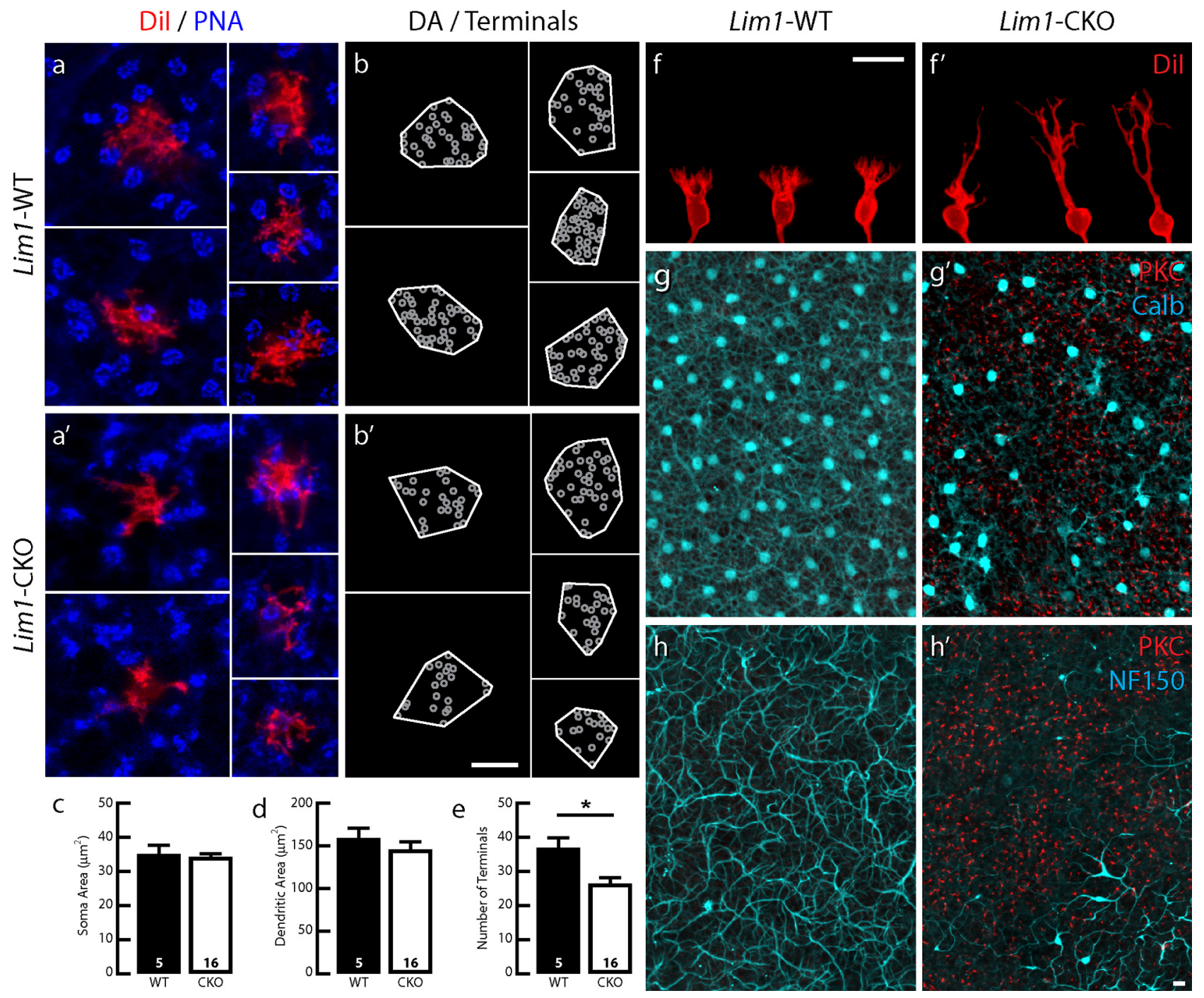

Figure 4. Rod bipolar cells exhibit extensive dendritic sprouting. Rod bipolar cells in the 2-month-old Lim1-CKO retina (red) extend dendritic arbors through the mosaic of cone pedicles (blue; $\boldsymbol{a}$, $\left.\boldsymbol{a}^{\prime}\right)$, establishing dendritic fields of comparable size $\left(\boldsymbol{b}, \boldsymbol{b}^{\prime}, \boldsymbol{d}\right)$. Somal area is not altered $(\boldsymbol{c}$ ), yet the number of dendritic tips is significantly reduced $(\boldsymbol{e})$. Those dendritic endings, however, are no longer confined to the OPL, but rather have become redistributed to the ONL via long sprouted dendrites $\left(\boldsymbol{f}, \boldsymbol{f}^{\prime}\right)$. These sprouted dendrites are evident in whole-mount preparations stained for PKC, never observed in the ONL of control retinas $\left(\boldsymbol{g}, \boldsymbol{h}\right.$ ), yet found in the Lim1-CKO retina (red) most frequently in regions depleted of horizontal cell somata (cyan; $\boldsymbol{g}^{\prime}$ ) or axons (cyan; $\boldsymbol{h}^{\prime}$ ). (Red and cyan channels shown in $\boldsymbol{g}, \boldsymbol{g}^{\prime}, \boldsymbol{h}$, and $\boldsymbol{h}^{\prime}$ are imaged through the ONL versus OPL, respectively, in each field using the horizontal cell labeling to determine the OPL/ONL boundary.) $n$, Number of labeled cells analyzed. Scale bars, $10 \mu \mathrm{m}$.

$\leftarrow$

(Figure legend continued.) throughout the ONL (d, $\boldsymbol{d}^{\prime}$, diagonal arrowheads). Note that retained PSD-95 in the OPL is associated with the pedicles $\left(\boldsymbol{h}, \boldsymbol{h}^{\prime}\right)$. Rod bipolar cells, labeled for PKC, sprout dendrites into the ONL (e, $\boldsymbol{e}^{\prime}$, diagonal arrows), their tips associating with ectopic CtBP2-labeled ribbons (i, $\boldsymbol{i}^{\prime}$, diagonal arrowheads). The distribution of mitochondria, labeled for cytochrome oxidase $(C O)$ in the $\mathrm{ONL}$, is unchanged $\left(\mathbf{j}, \boldsymbol{j}^{\prime}\right)$. (The Reep6 labeling has been omitted from the ONL in these images for clarity, but shows convincingly, in the OPL, that this region of retina contains a loss of rod spherules). Structural reorganization of rod photoreceptors was confirmed in 3D serial EM reconstructions, showing a complete retraction of the spherule to the soma itself $\left(\boldsymbol{k}, \boldsymbol{k}^{\prime}\right)$. A single spherule arising from a rod photoreceptor soma in the WT retina is shown $(\boldsymbol{k})$, along with two horizontal cell axon terminals (cyan and yellow processes) and two rod bipolar dendritic terminals (green and pink) reconstructed from their invaginations into the spherule. Four rod photoreceptor somas in the CKO retina were also reconstructed, none of which extended a process vitreally $\left(\boldsymbol{k}^{\prime}\right)$. In one instance, two rod bipolar processes invaginate into a slight basally directed extension of the soma, one of them from one of the two sprouted rod bipolar cells (green and pink), indicated by the arrowhead $\left(\boldsymbol{k}^{\prime}\right)$. Six micrographs through the site of this invagination (arrowhead) are shown ( $\boldsymbol{I}^{\prime}$; pink process). Another process (yellow) presumably arises from a neighboring rod bipolar cell (not reconstructed). Scale bars: $\boldsymbol{a}-\boldsymbol{j}, 10$ $\mu \mathrm{m} ; \boldsymbol{k}-\mathbf{I}, 5 \mu \mathrm{m}$
CKO (Fig. $4 g^{\prime}, h^{\prime}$ ); as expected, no PKC-positive dendrites were observed in the ONL of the littermate control retinas (Fig. $4 g, h$ ).

\section{Sprouting is associated with a redistribution of dendrites} from the OPL

The PKC-positive rod bipolar cells in the Lim1-CKO retinas not only exhibited sprouting into the ONL, but also showed a loss of fine dendritic endings at the level of the ONL/INL border (Fig. $\left.3 e^{\prime}\right)$. The single-labeled rod bipolar cells showed this more clearly, lacking the fine spray of dendrites normally present at this level (Fig. $4 f^{\prime}$ ). Some of these rod bipolar cells had a morphology suggesting a transitional stage, exhibiting a few processes emerging nearer the soma and a coarser stalk ascending into the ONL, but lacking the more robust branching in the distal ONL (Fig. $4 f^{\prime}$, far left cell). The somal and dendritic field areas of rod bipolar cells in the CKO were no different from those in wild-type retinas (Fig. $4 c, d$ ), although a significant reduction in the total number of dendritic endings was detected in these remodeled cells (Fig. $\left.4 b, b^{\prime}, e\right)$. 
Lim1-WT
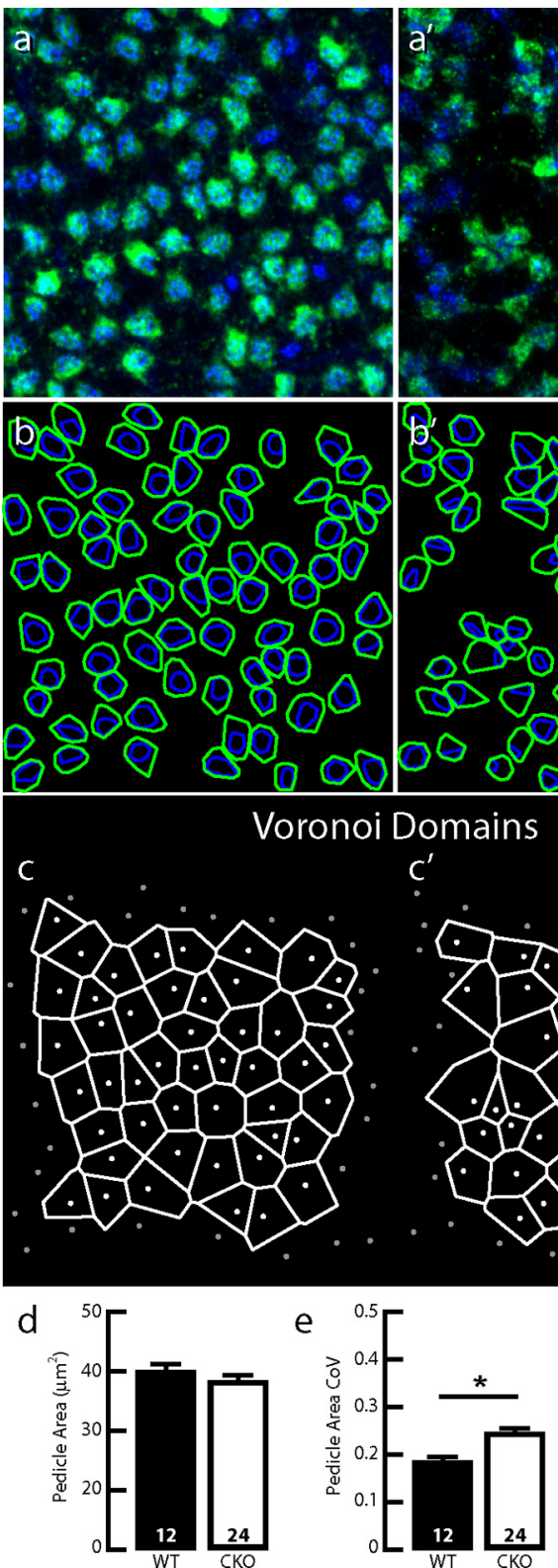

Lim1-CKO
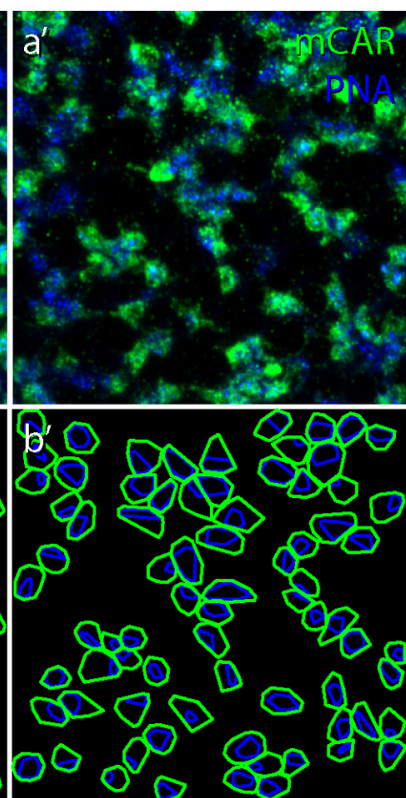

Domains
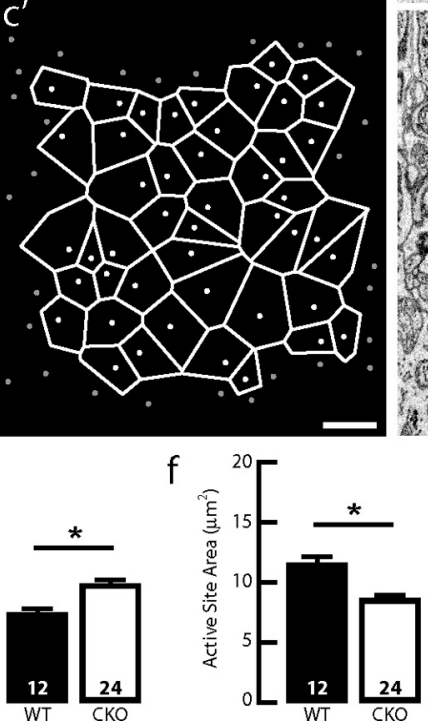

Lim1-WT
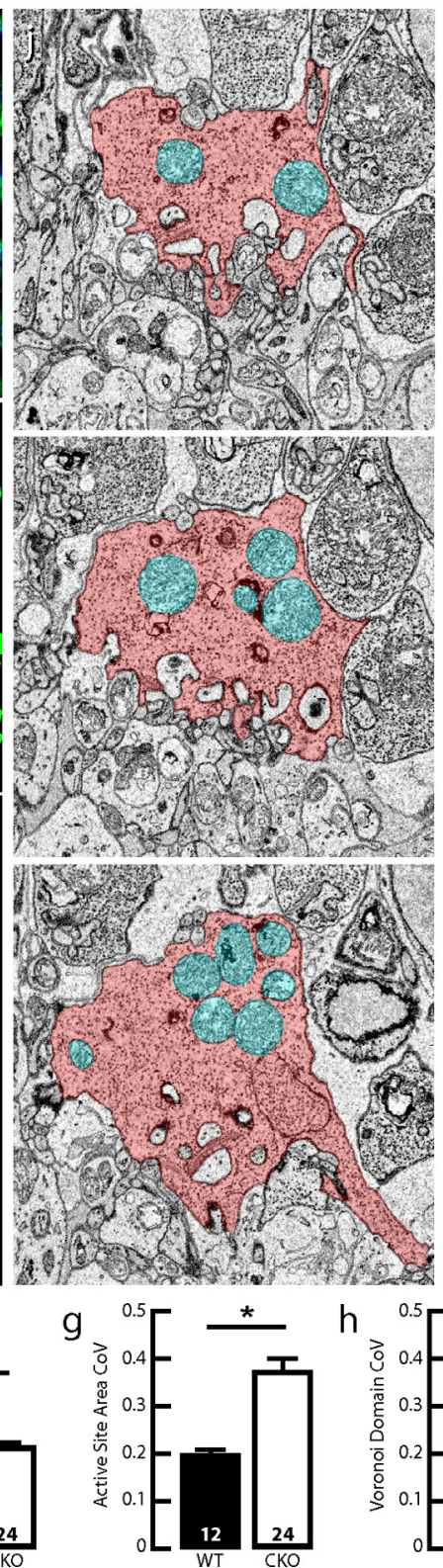
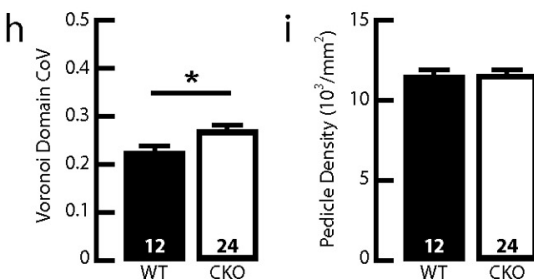

Figure 5. Cone pedicles are atrophic and disordered within the OPL. Cone pedicle density and average size are unchanged in the 2-month-old Lim 1 -CKO retina ( $g$ reen; $\boldsymbol{a}, \boldsymbol{a}^{\prime}, \boldsymbol{b}, \boldsymbol{b}^{\prime}, \boldsymbol{d}, \boldsymbol{i}$ ), but the area of the PNA-positive active sites of the pedicles is reduced (blue; $\left.\boldsymbol{a}, \boldsymbol{a}^{\prime}, \boldsymbol{b}, \boldsymbol{b}^{\prime}, \boldsymbol{f}\right)$, and both pedicle area and active site area show more variability in size (e, $\boldsymbol{g}$ ). Spacing between the pedicles is also more variable, evidenced by the sizes of their Voronoi domains $\left(\boldsymbol{c}, \boldsymbol{c}^{\prime}, \boldsymbol{h}\right)$. Pedicles (pink) in the Lim 1-CKO retina contain fewer mitochondria (cyan) and invaginating processes $\left(\boldsymbol{j}, \boldsymbol{j}^{\prime}\right)$. $n$, Number of fields analyzed. Scale bars, $10 \mu \mathrm{m}$.

Cone pedicle morphology and spacing are disrupted in the

\section{Lim 1-CKO retina}

While cone pedicles retained their normal stratification in the Lim1-CKO retina despite the loss of horizontal cell processes, their morphology and spacing were disturbed (Fig. $3 c^{\prime}$ ). This was more readily apparent in whole-mount preparations. There, the size of the cone pedicles (labeled with MCAR) in the Lim1-CKO was comparable on average to that seen in control retinas (Fig. $5 a, b, a^{\prime}, b^{\prime}$, green; $d$ ), although significantly more variable within a field (Fig. $5 e$ ). Even more conspicuous was the apparent disorder of their active sites, revealed by labeling for PNA (Fig. $5 a, b, a^{\prime}, b^{\prime}$, blue). The area of each polygon enclosing these active sites was significantly smaller (Fig. $5 f$ ) and was more variable (Fig. 5g), despite the lack of a significant reduction in average pedicle size
(Fig. 5d). Ultrastructural observations were consistent with this apparent active site atrophy: fewer invaginating elements were detected in a reconstructed $\mathrm{CKO}$ pedicle and there was a reduction in the number of mitochondria present (Fig. $5 j, j^{\prime}$ ). Pedicle spacing was also significantly perturbed, as evidenced by the greater variability in the Voronoi domains associated with each pedicle (Fig. $5 c, c^{\prime}, h$ ). Greater spaces devoid of pedicles were observed within the pedicle matrix (Figs. $3 c^{\prime}, 5 a^{\prime}$ ), but this was not a consequence of cone loss because the average density of mCARpositive cone pedicles was not affected (Fig. 5i).

Cone bipolar cell dendritic arbors are atrophic

Type 7 cone bipolar cells in the Lim1-CKO retina retained their characteristic stratification and association with the population 

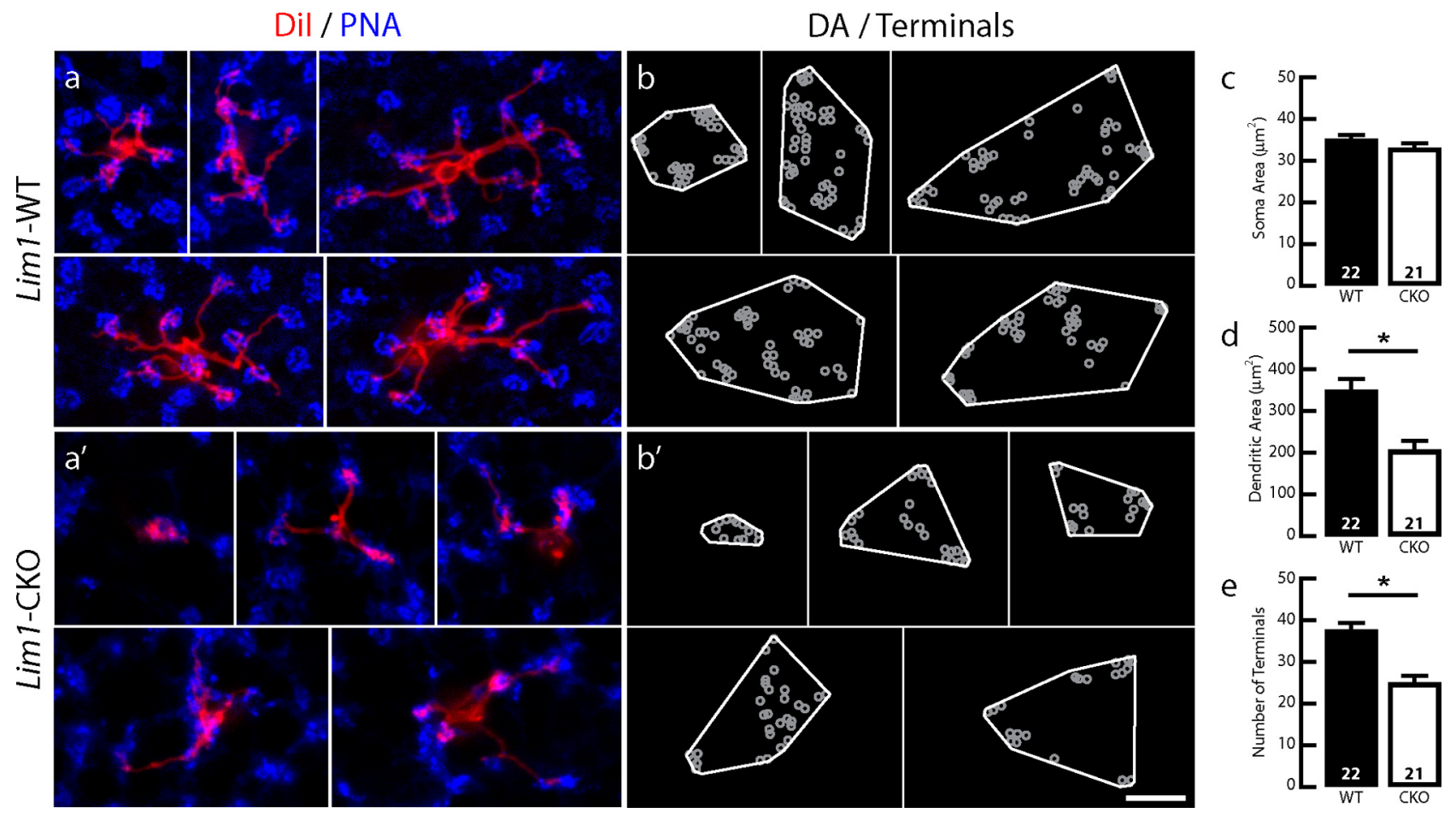

Figure 6. Cone bipolar cells exhibit atrophic changes while retaining their characteristic association with cone pedicles in the OPL. Single cone bipolar cells extend dendrites $\left(\boldsymbol{a}, \boldsymbol{a}^{\prime}\right.$, red) that contact the PNA-labeled active sites of those cone pedicles $\left(\boldsymbol{a}, \boldsymbol{a}^{\prime}\right.$, blue), having comparable somal areas ( $\boldsymbol{c}$ ) yet producing smaller dendritic fields ( $\left.\boldsymbol{d}\right)$ and forming a smaller total number of dendritic endings at those pedicles $\left(\boldsymbol{b}, \boldsymbol{b}^{\prime}, \boldsymbol{c}\right)$. n, Number of labeled cells analyzed in $\boldsymbol{c}-\boldsymbol{e}$. Scale bars, $10 \mu \mathrm{m}$.

of pedicles, but nevertheless appeared abnormal in features directly related to the altered pedicle spacing and active site atrophy. The dendritic arbors of single type 7 cone bipolar cells in control retinas localized nearly exclusively to the active sites of the cone pedicles, but in the Lim1-CKO retinas, they had significantly smaller dendritic fields (Fig. $6 a, a^{\prime}, b, b^{\prime}, d$ ) and appeared to contact a smaller number of pedicles. Although this latter feature could not be quantified because the active site labeling between these clustered pedicles in the Lim 1-CKO retinas could often not be discriminated (Fig. $6 a^{\prime}$, blue pedicles), unlike in the control retinas (Fig. 6a; see also Keeley and Reese, 2010; Lee et al., 2011), a significant reduction in the total number of dendritic terminal endings per cone bipolar cell was detected (Fig. 6e). Again, because pedicle density was unaltered (Fig. 5i), this change in the total number of dendritic endings cannot be due to a loss of afferents; rather, it should be associated with the atrophy of the active sites at the pedicles themselves, but the causal relationship between them remains to be determined.

Assembly of the OPL does not require the horizontal cells Horizontal cells require $\operatorname{Lim} 1$ to migrate to their correct position in the INL during embryonic development (Poché et al., 2007); in concordance, horizontal cell processes were absent from the OPL of the Lim1-CKO retina at early postnatal ages. By postnatal day 9 (P9), when OPL formation is normally well under way (Sherry et al., 2003), the Lim1-CKO retina already showed a reduced thickness of the OPL (Fig. $7 a^{\prime}$, red arrow) and a lack of calbindin (Fig. $\left.7 b^{\prime}\right)$ and NF150 immunoreactivity (data not shown) therein (compare Fig. 7a,b). Despite the lack of horizontal processes, an apparently normal complement of evenly distributed, CtBP2positive profiles was present across the thin OPL of the Lim1CKO retina (Fig. $7 c, c^{\prime}$ ). Not all of these were associated with cone pedicles, which have already differentiated and stratified within the OPL (Fig. $7 d, d^{\prime}$ ), indicating that the remaining CtBP2positive puncta in the nascent OPL should be the sites of developing rod spherules (Fig. $7 f, f^{\prime}$ ). Coincident with this stratum of CtBP2-positive profiles across the developing OPL, PKC-positive rod bipolar cell dendrites have initiated their dendritic stratification within the OPL, being comparable to that present in control retinas (Fig. $7 e, e^{\prime}, g, g^{\prime}$ ).

\section{Rod bipolar cell dendritic sprouting follows the retraction of} rod spherules

After P9, control retinas showed a continuing expansion of the rod spherule-associated CtBP2-positive stratum within the OPL (Fig. $8 a-c)$. In parallel, the rod bipolar cells continued their dendritic growth to fill the OPL (Fig. 8d-f). Lim1-CKO retinas, in contrast, showed a progressive loss of Reep6-positive spherules and their associated (CtBP2-positive) ribbons (Fig. $8 a^{\prime}-c^{\prime}$ ). By P13, when ectopic CtBP2-positive puncta can be detected within the ONL, and the OPL is already showing a depletion of ribbons, the population of rod bipolar cells shows no signs of sprouting at this age (Fig. $8 d^{\prime}$ ). Only thereafter was the sprouting phenotype conspicuous in PKC-stained tissue (Fig. 3e'), being first detected around P21 (Fig. 8 $e^{\prime}$, diagonal arrows); these dendritic sprouts, however, did not terminate at CtBP2-positive puncta, suggesting that the two synaptic partners are initially decoupled, only to reconnect later in maturity. These sprouted rod bipolar dendrites could still be detected in the ONL at late as 7 months of age (the latest age examined), when their terminal branches continued to associate with ectopic CtBP2 puncta (Fig. $8 f^{\prime}$, diagonal arrows; see also Fig. $3 i^{\prime}$ ).

Sprouting is not associated with neuronal loss in the Lim1-

\section{CKO retina}

This rod pathway plasticity was not associated with cellular loss in the retina of these older Lim1-CKO mice. At 7 months of age, 


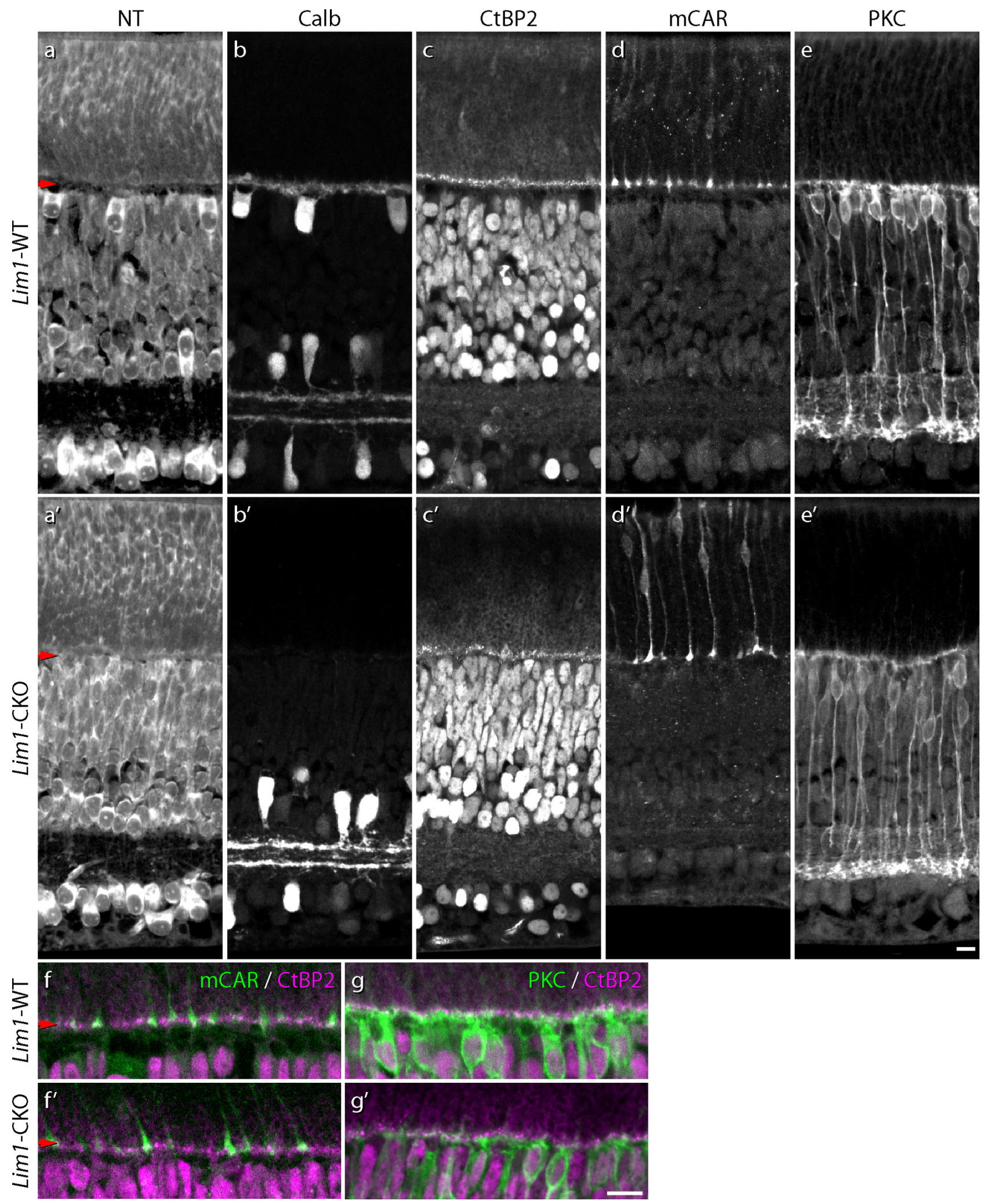

Figure 7. Horizontal cells are not required for the initial stratification and connectivity associated with both the rod and cone pathways. Despite the absence of horizontal cells before the onset of OPL formation, ribbon formation and rod bipolar cell dendritic outgrowth develop normally. By P9, in regions devoid of a cell sparse OPL $\left(\boldsymbol{a}, \boldsymbol{a}^{\prime}\right)$ lacking horizontal cells and their processes $\left(\boldsymbol{b}, \boldsymbol{b}^{\prime}\right)$, a continuous stratum of CtBP2-positive puncta defines an emerging OPL $\left(\boldsymbol{c}, \boldsymbol{c}^{\prime}\right)$; cone pedicles are properly stratified at this age $\left(\boldsymbol{d}, \boldsymbol{d}^{\prime}\right)$, but do not account for all of the CtBP2-positive profiles $\left(\boldsymbol{f}, \boldsymbol{f}^{\prime}\right)$. At this age, PKC-positive rod bipolar cells have differentiated dendrites that are confined to this stratum $\left(\boldsymbol{e}, \boldsymbol{e}^{\prime}, \boldsymbol{g}, \boldsymbol{g}^{\prime}\right)$. Scale bars, $10 \mu \mathrm{m}$. 

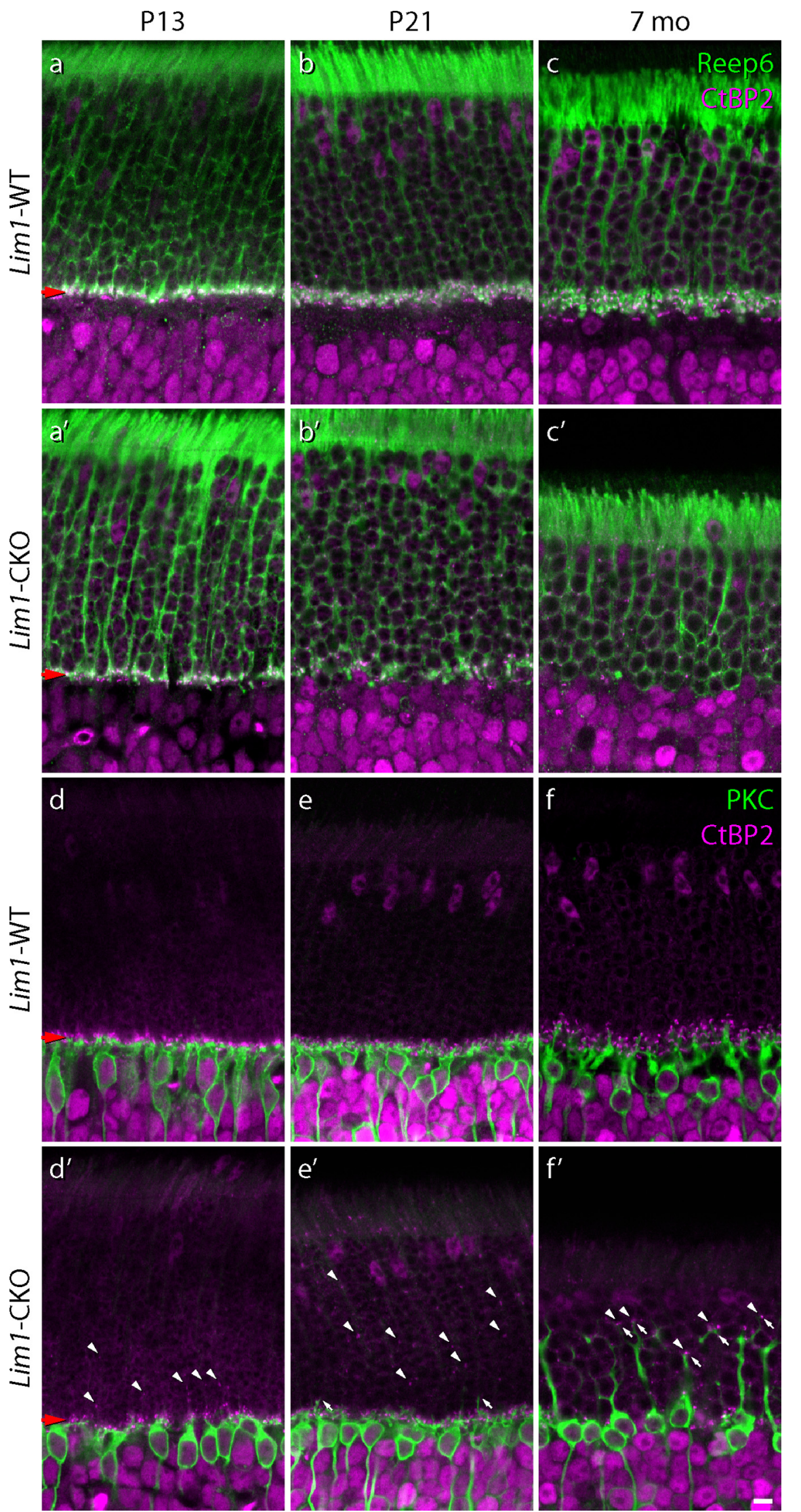

Figure 8. The rod pathway is transiently disconnected before the rod bipolar cells remodel their dendritic arbors. Following initial OPL formation, the population of rod spherules (green) and their associated synaptic ribbons (magenta) in the Lim 1-CKO retina are progressively eliminated $\left(\boldsymbol{a}^{\prime}-\boldsymbol{c}^{\prime}\right)$, whereas in control retinas, these both expand within a larger cell-sparse OPL (a-c). Sprouting of rod bipolar cell dendrites is delayed relative to the elimination of spherules from the OPL in the Lim1-CKO retina ( $\boldsymbol{d}^{\prime}, \boldsymbol{e}^{\prime}$ rods showed a slight, yet nonsignificant, decline in neuronal number in the CKO retinas (Fig. $9 a, a^{\prime}, b$ ). To investigate whether that nonsignificant decline might conceal a mosaicism in the loss of rod photoreceptors, the $\mathrm{CoV}$ associated with rod density measures taken across the multiple fields sampled in a $1 \mathrm{~mm}$ square grid across each retina (minimum of 13 fields per retina) was also calculated $($ Lim1-CKO $=0.12 \pm 0.011$, mean and SEM); however, these CoVs were not significantly different from those of control retinas $(0.11 \pm 0.014)$. The population of PKC-positive rod bipolar cells itself did not exhibit any decline from values in control retinas (Fig. $9 c, c^{\prime}, d$ ). Because the cone pedicles were found to be atrophic at P60, we also estimated the total cone photoreceptor and type 2 cone bipolar cell populations in 7-month-old retinas by counting all cone opsin-positive outer segments (Fig. 9e, $e^{\prime}$ ) and Syt2-positive axons (Fig. $9 g, g^{\prime}$ ), respectively, finding no significant difference in either population (Fig. $9 f, h)$. Notwithstanding the possibility that a very slow, if meager, loss of rod photoreceptors occurs in the Lim1-CKO retina (although immunostaining for activated caspase- 3 failed to reveal a single positive cell in the ONL in either control or CKO retinas at 2 or 7 months of age; $n=1$ per condition, sampling the entire retina), these results suggest that the sprouting of rod bipolar cell dendrites, like the atrophy of cone bipolar cell dendrites, is not triggered by neuronal loss.

\section{Sprouting of rod bipolar cells becomes progressively widespread in maturity} To examine the prevalence of rod bipolar sprouting as a function of age across the retina, Lim1-CKO retinal whole mounts at different ages up to 7 months of age were stained for PKC, sampled through the depth of the ONL only, and reconstructed as single high-resolution images of the entire retina. At P21, minimal sprouting in the ONL was detected (Fig. 10a, $a^{\prime}$ ), consistent with the analysis of sectioned material at this age (Fig. $8 e^{\prime}$ ). Thereafter, the extent of sprouting through the depth of the ONL increased, as shown in the sectioned

green) as ectopic ribbons begin to materialize in the ONL $\left(d^{\prime}, e^{\prime}\right.$, magenta, diagonal arrowheads). Rod bipolar cells ultimately produce large dendritic sprouts that reach deep into the 0NL ( $\boldsymbol{f}^{\prime}$, diagonal arrows), associating with CtBP2-positive ribbons ( $\boldsymbol{f}^{\prime}$, diagonal arrowheads). Note as well the complete elimination of the spray of fine dendritic terminations normally present at the boundary between the ONL and INL. Scale bar, $10 \mu \mathrm{m}$ 
material (Fig. $8 f^{\prime}$ ), but increasingly more of the areal extent of the retina contained this sprouting in the ONL (Fig. 10b-d; highermagnification images are shown in Fig. $\left.10 b^{\prime}-d^{\prime}\right)$. Some regions still lacked any sprouting, presumably because fewer, if any, horizontal cells in these regions had undergone recombination and so remained present within the outer retina. That different quadrants of the retina might be expected occasionally to show such large differences in levels of sprouting (Fig. 10d) is suggested by the images in Figure 10e, showing crosssections from one Lim1-CKO retina (at P60) imaged at three eccentricities on each side of the optic nerve head, revealing an asymmetry in the depletion of the population of horizontal cell axons. Notice the loss of NF-150 labeling in the right three panels and the corresponding reduction in the thickness of the OPL, whereas the left three panels show the presence of limited NF-150 labeling within a cell-free OPL. Although some of the unaffected regions at 7 months of age (Fig. 10d) must reflect such a lack of effective cre-mediated recombination (Fig. $10 e$ ), there was still a slow, progressive prevalence of sprouting across other regions of retina, and this may simply indicate that sprouting proceeds at a rate that is proportional to the degree of horizontal cell depletion within a region. Our sectioned material in this study necessarily focused upon regions with a collapsed OPL to illustrate the characteristic changes therein, but many regions upon the retina may contain lessreduced densities of horizontal cell processes and these may be the regions that exhibit progressively slower sprouting.

\section{Discussion}

We have demonstrated conclusively that, despite their early production (Young, 1985), migration (Huckfeldt et al., 2009), mosaic assembly (Raven et al., 2005), and morphological differentiation (Reese et al., 2005), horizontal cells do not play a critical role in directing the initial stratification of photoreceptor and bipolar processes within the OPL. Specifically, the Lim1-CKO mouse retina causes a mispositioning of embryonic horizontal cells to the inner retina (Poché et al., 2007), thereby depleting the outer retina of this early neuronal constituent. Despite their absence, the terminals of the rod and cone photoreceptors assemble in their normal strata within the OPL, where they localize synaptic and other proteins characteristic of their mature organization. Their postsynaptic partners, the rod bipolar cells and cone bipolar cells, also direct their dendritic terminals to these respective strata and associate with their correct presynaptic partners by the beginning of the second postnatal week, when contacts between the two cell types are normally forming (Sherry et al., 2003; Morgan et al., 2006). Thereafter, this bars, $10 \mu \mathrm{m}$.
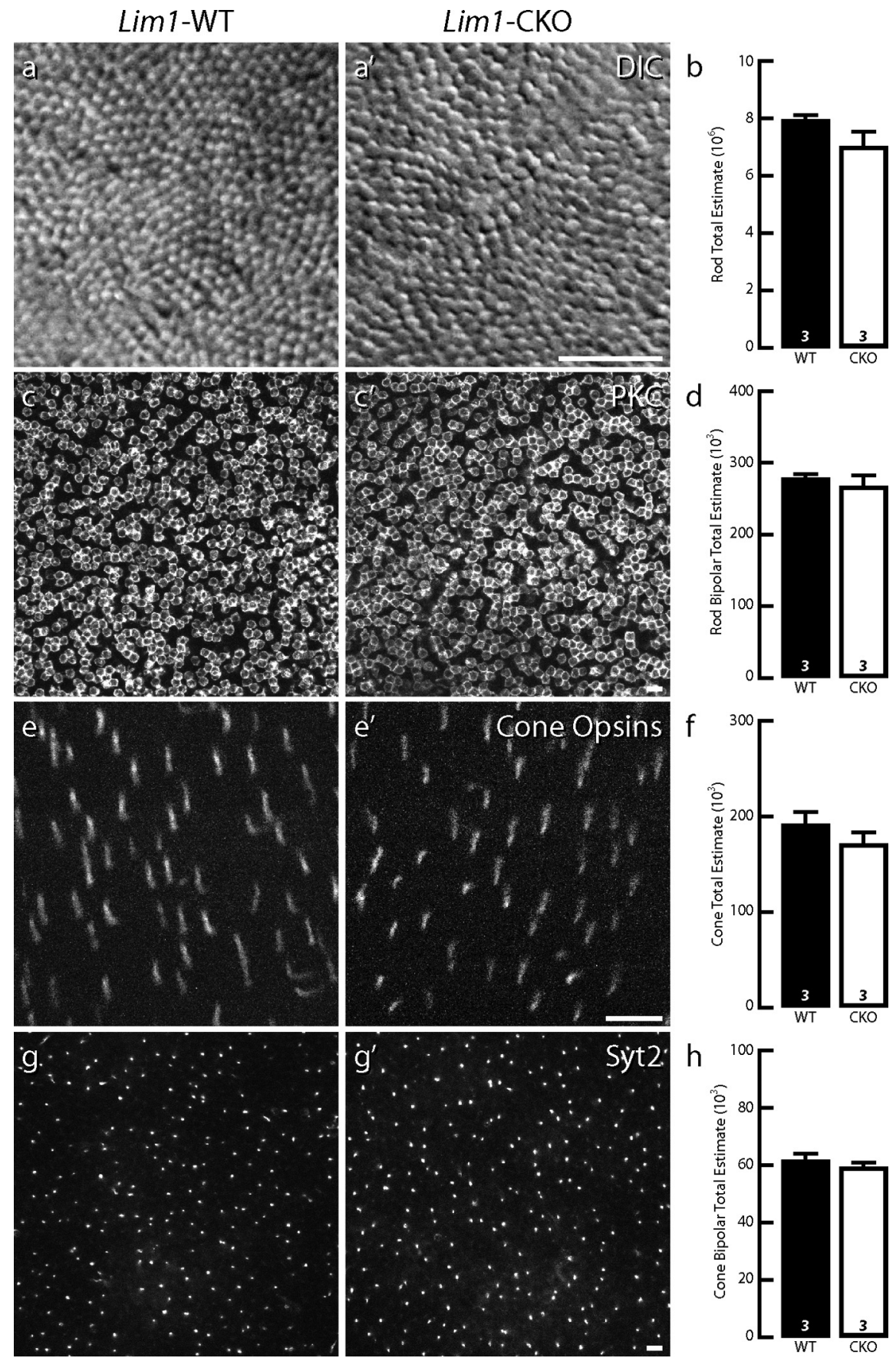

Figure 9. Changes in the rod and cone pathways are not a consequence of cell death. Massive sprouting by rod bipolar cell dendrites at 7 months of age is not associated with cell loss within the population of rod photoreceptors $\left(\boldsymbol{a}, \boldsymbol{a}^{\prime}, \boldsymbol{b}\right)$, nor with any significant elimination of rod bipolar cells themselves $\left(\boldsymbol{c}, \boldsymbol{c}^{\prime}, \boldsymbol{d}\right)$. In addition, there is no loss of cone photoreceptors $\left(\boldsymbol{e}, \boldsymbol{e}^{\prime}, \boldsymbol{f}\right)$, nor of one type of cone bipolar cell (the type 2 cell; $\boldsymbol{g}_{\boldsymbol{\prime}} \boldsymbol{g}^{\prime}, \boldsymbol{h}$ ) despite the atrophy of their afferents. $n$, Number of retinas analyzed. Scale early depletion of horizontal cells from the outer retina yields progressively severe consequences for the morphology of the photoreceptor and bipolar cell populations, but are quite distinctive for the rod versus cone pathways. Changes in the cone pathway were characterized by an atrophy of both the cone pedicles and the cone bipolar dendrites, but these cells retained their association with one another. The changes in the rod pathway, in contrast, were more dynamic and included the progressive retraction of the rod spherules from the OPL and the subsequent remodeling of the rod bipolar cell dendrites. The latter were first 


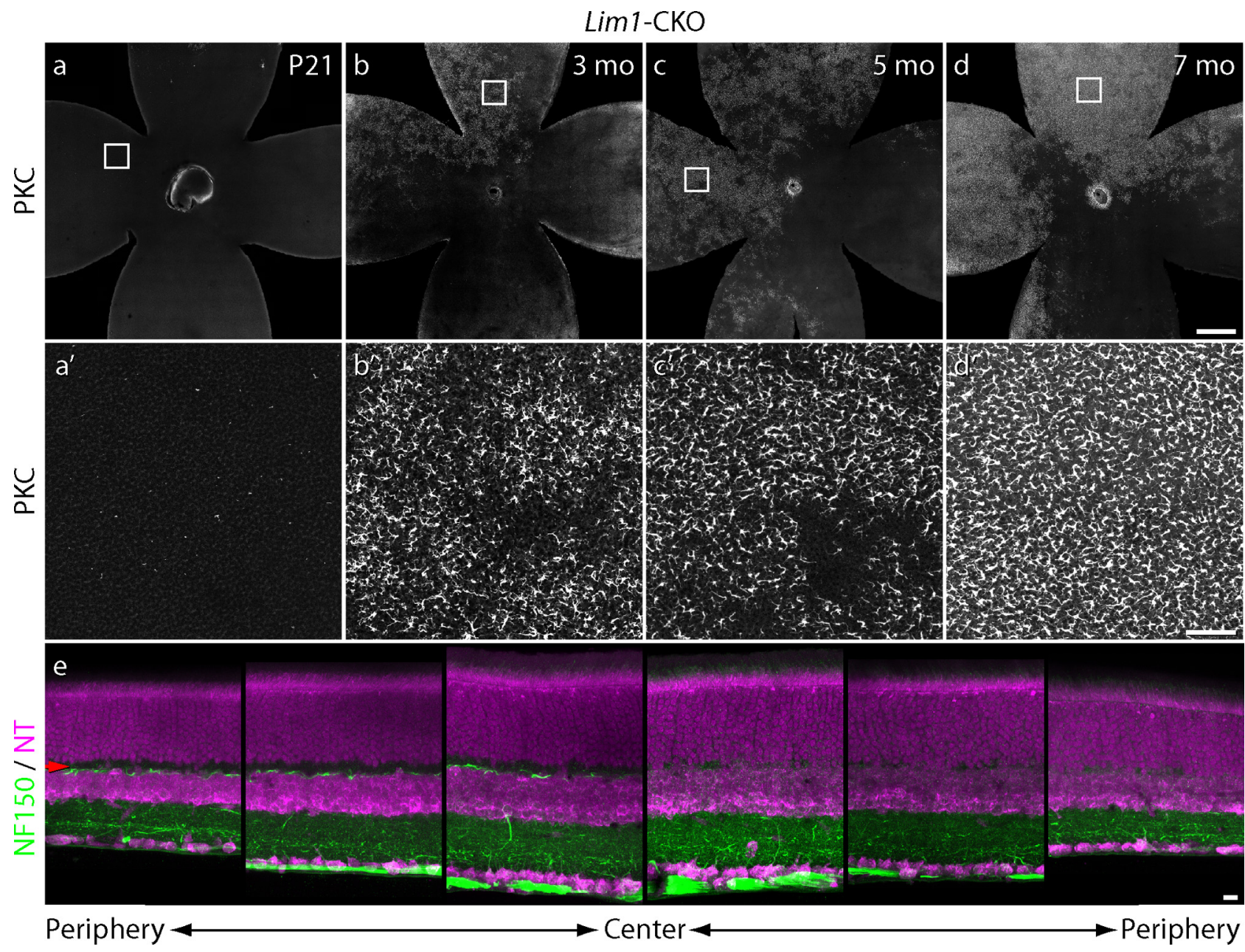

Figure 10. Dendritic sprouting becomes increasingly pervasive across the retina at later stages. Almost no PKC-positive sprouts reach into the ONL by P21 (a, $\left.\boldsymbol{a}^{\prime}\right)$, but thereafter become increasingly widespread $\left(\boldsymbol{b}, \boldsymbol{b}^{\prime}, \boldsymbol{c}, \boldsymbol{c}^{\prime}\right)$. Nearly a quadrant of retina lacks sprouting into the $0 \mathrm{NL}$ in this 7-month-old retina $\left(\boldsymbol{d}, \boldsymbol{d}^{\prime}\right)$, suggesting a lack of much cre-mediated recombination in the population of horizontal cells in this region during early development. Indeed, sections from a 2-month-old retina showed marked differences in the degree of elimination of horizontal cell processes from the OPL on opposite sides of the optic nerve head (e), consistent with this interpretation. Scale bars: $\boldsymbol{a}-\boldsymbol{d}, 500 \mu \mathrm{m} ; \boldsymbol{a}^{\prime}-\boldsymbol{d}^{\prime}, 50 \mu \mathrm{m}$; and $\boldsymbol{e}, 10 \mu \mathrm{m}$.

observed to decouple from the spherules and then sprout large dendritic stalks that ascended into the ONL. These in turn branched distally, associating with ectopic CtBP2-puncta localized within the ONL itself. These results make clear that, although horizontal cells may not be necessary for the initial organization of the OPL, they are critical for maintaining its integrity.

\section{Remodeling of the rod pathway}

The rod pathway has been shown to be highly plastic in several other outer retinal perturbations, including impairments of synaptic transmission (Dick et al., 2003; Haeseleer et al., 2004; Mansergh et al., 2005; Chang et al., 2006; Bayley and Morgans, 2007; Specht et al., 2007), retinal detachment (Lewis et al., 1998; Fisher and Lewis, 2003; Fisher et al., 2005), senescence (Liets et al., 2006), and, most recently, loss of horizontal cells from the mature (Sonntag et al., 2012) or developing (Wu et al., 2013) retina. These studies share some of the features reported here, including the redistribution of synaptic proteins and the remodeling of rod bipolar cells, although none reports the temporal sequence of events observed herein regarding the sequential remodeling of the rod bipolar cell dendrites nor the structural evidence of retracted spherules. The present study shows an initial disconnection between the rods and the rod bipolar cells, when the latter undergo a dendritic remodeling after the spherules disassemble from the OPL, eventually yielding a robust sprouting deep into the ONL, branching to terminate at the sites of ectopic $\mathrm{CtBP} 2$ puncta. The role of the horizontal cell axonal arbor in stabilizing this association, however, remains obscure.

We suspect that there are two possible mechanisms underlying this maintenance by horizontal cells: the horizontal cell may act either through the expression of specific cell adhesion molecules or it may prevent destabilization by regulating synaptic activity, both established mechanisms of synaptic plasticity (Wong and Ghosh, 2002; Dalva et al., 2007). For example, netrin-G ligand 2 (NGL-2) has recently been shown to localize to the tips of the horizontal cell axonal arbor, being a potential molecular candidate, but NGL-2 mutants do not show sprouting of rod bipolar cell dendrites (Soto et al., 2013). Neural transmission has been shown to play a critical role in maintaining this synapse, because silencing the rod photoreceptor by removing specific ion channels or ribbon proteins causes rod spherule retraction and rod bipolar sprouting (Dick et al., 2003; Haeseleer et al., 2004; Mansergh et al., 2005; Chang et al., 2006; Bayley and Morgans, 2007; Specht et al., 2007). Halting GABA transmission in horizontal cells, in contrast, does not appear to have any consequence on the assembly and maintenance of the OPL (Schubert et al., 2010), 
suggesting an activity-independent mechanism of stabilization by horizontal cells. Interestingly, this plasticity in the rod pathway is replicated in aged wild-type retinas (Liets et al., 2006), raising the possibility that the maintenance function of the horizontal cell may naturally degrade with senescence, perhaps by downregulating cell adhesion molecules that maintain the synapse.

It is curious that such comparable outcomes are derived when horizontal cells are eliminated before the formation of the OPL as well as after a fully mature OPL has assembled (Sonntag et al., 2012), because the axon terminal system of the horizontal cells is believed to invaginate the spherules before the rod bipolar cells (Sherry et al., 2003) and might have been expected to yield a more destabilizing effect consequent to their early removal. Although genetic elimination of the homeodomain transcription factor Onecut1 (Oc1) has also been shown recently to reduce the horizontal cell population and to produce sprouting of rod bipolar cells in the mature retina, $O c 1$ is not expressed exclusively by horizontal cells and the mutant retina displays conspicuous cell loss within the ONL, rendering unclear the causal relationships to the rod bipolar cell remodeling therein (Wu et al., 2013). The elimination of mature horizontal cells that yields sprouting of rod bipolar cells also produced a significant loss of photoreceptors (Sonntag et al., 2012). Nevertheless, the present study, examined at a comparable time point to these studies, failed to show evidence of photoreceptor loss, leading to the conclusion that the effect upon rod bipolar cell sprouting is not mediated by photoreceptor degeneration. Indeed, it is somewhat remarkable that these rod photoreceptors, relieved of their presynaptic endings, continue to survive, although we cannot rule out the possibility of a trophic effect mediated by the sprouted rod bipolar cell dendrites. Whatever the feature associated with horizontal cells critical for maintaining the normal relationship between rod spherules and rod bipolar cell dendrites, it clearly is not required for the initial assembly and stratification of the OPL.

\section{Atrophy of the cone pathway}

As with the rod pathway, the components of the cone pathway differentiate normally during early postnatal development in the Lim1-CKO retina. By the close of the second postnatal week, however, the disrupted cone pedicle patterning, which is so clear in maturity, has begun to materialize and the PNApositive active sites are compromised relative to control retinas (data not shown). The dendrites of the horizontal cells normally form periodic clusters of terminal endings associated with the pedicle mosaic only after P10 (Reese et al., 2005), suggesting that those clustered dendritic endings might help to stabilize the positioning of the pedicles around this time. The pedicles may also aggregate in the absence of the horizontal cells as a passive consequence of the collapse of the OPL in the Lim1-CKO retina, and the fact that this clustering occurs even after horizontal cell ablation in the mature retina (Sonntag et al., 2012) is consistent with this interpretation. The changes in the pedicle mosaic are not simply a consequence of the loss of a postsynaptic target, because a substantial early depletion of the bipolar cell population (as observed in the Isl1-CKO mouse) does not degrade the pedicle mosaic, even though those pedicles show an atrophy of their active sites (Lee et al., 2011), as in the Lim1-CKO mouse (Fig. 5). Those same Isl1-CKO retinas do not show a collapse of the OPL nor a loss of synaptic ribbons (Lee et al., 2011), indicating that the change in the spatial relationship between the pedicles described herein is uniquely dependent upon the horizontal cells and should be unrelated to the atrophy associated with the pedicles themselves. That atrophy, specifically the reduction in the size of the active site area despite no loss in the size of the pedicles themselves (Fig. $5 d, f$ ), may be a simple consequence of the loss of postsynaptic elements invaginating into the pedicle itself.

Unlike the rod bipolar cells, cone bipolar cells, at least the type 7 ON-cone bipolar cells, do not show evidence of substantial remodeling, retaining much of their characteristic dendritic organization and connectivity with cone pedicles. Their dendritic endings continued to terminate at PNA-positive active sites on the cone pedicle, as seen in wild-type retinas, indicating that the demarcation of this territory across the pedicle does not require horizontal cell input. The type 7 cone bipolar cells did show signs of atrophy, however, in the form of smaller dendritic fields and fewer dendritic terminal endings. These too may be independent of one another: the smaller dendritic fields may simply be a consequence of the clustering of pedicles across a smaller territory, while the decline in dendritic terminal endings may correlate with the decline in active site area upon the pedicle (each showing reductions of $28 \%$ and $26 \%$, respectively; compare Fig. $6 e$, Fig. $5 f$ ), both potentially indicative of the presence of fewer synaptic ribbons at the pedicle.

As atrophic as this cone pathway appears, it is important to stress that cones are not lost in the Lim1-CKO retina, evidenced either at 2 months of age by comparing pedicle densities when these atrophic features are already present (Fig. 5i) or at 7 months of age as evidenced by estimating the total population of cone outer segments within the retina (Fig. 9f). To look for other signs of atrophy that might affect the OPL, we also counted a type of OFF-cone bipolar cell, the type 2 cell, but found no difference between control and Lim1-CKO retinas and verified that the remodeling of rod bipolar cells was not associated with any cellular loss within this population as well. We also estimated the size of the rod photoreceptor population and, although we observed a slight trend in the direction consistent with rod loss, it did not reach statistical significance (Fig. 9b). Together, our studies suggest that the atrophic and remodeling changes in the cone and rod pathways are not a secondary manifestation of retinal degeneration, but rather reflect the maintenance actions of horizontal cells upon the connectivity within the OPL itself.

\section{Conclusions}

Numerous studies, both within the visual system and elsewhere in the CNS, have revealed the necessity of molecular and/or neural components for directed targeting and association between different components of a developing circuit (Fox and Wong, 2005; Frotscher et al., 2007; Betley et al., 2009; Sanes and Yamagata, 2009; Sotelo and Dusart, 2009; Huberman et al., 2010). Others have shown a requirement of various components for the preservation of connectivity in mature retina (Raisman, 1994; Marc et al., 2003; Wieloch and Nikolich, 2006). The present study clearly demonstrates that removal of a single component (in this case, the horizontal cell) neither prevents the assembly of the stratifying architecture of the OPL nor the association between other presynaptic and postsynaptic components therein, but it is essential for maintaining the stratification and colocalization after synaptic assembly. 


\section{References}

Bayley PR, Morgans CW (2007) Rod bipolar cells and horizontal cells form displaced synaptic contacts with rods in the outer nuclear layer of the nob2 retina. J Comp Neurol 500:286-298. CrossRef Medline

Betley JN, Wright CV, Kawaguchi Y, Erdélyi F, Szabó G, Jessell TM, Kaltschmidt JA (2009) Stringent specificity in the construction of a GABAergic presynaptic inhibitory circuit. Cell 139:161-174. CrossRef Medline

Blanks JC, Johnson LV (1983) Selective lectin binding of the developing mouse retina. J Comp Neurol 221:31-41. CrossRef Medline

Chang B, Heckenlively JR, Bayley PR, Brecha NC, Davisson MT, Hawes NL, Hirano AA, Hurd RE, Ikeda A, Johnson BA, McCall MA, Morgans CW, Nusinowitz S, Peachey NS, Rice DS, Vessey KA, Gregg RG (2006) The nob2 mouse, a null mutation in Cacnalf: anatomical and functional abnormalities in the outer retina and their consequences on ganglion cell visual responses. Vis Neurosci 23:11-24. CrossRef Medline

Dalva MB, McClelland AC, Kayser MS (2007) Cell adhesion molecules: signalling functions at the synapse. Nat Rev Neurosci 8:206-220. CrossRef Medline

Dick O, tom Dieck S, Altrock WD, Ammermüller J, Weiler R, Garner CC, Gundelfinger ED, Brandstätter JH (2003) The presynaptic active zone protein bassoon is essential for photoreceptor ribbon synapse formation in the retina. Neuron 37:775-786. CrossRef Medline

Fisher SK, Lewis GP (2003) Müller cell and neuronal remodeling in retinal detachment and reattachment and their potential consequences for visual recovery: a review and reconsideration of recent data. Vision Res 43:887897. CrossRef Medline

Fisher SK, Lewis GP, Linberg KA, Verardo MR (2005) Cellular remodeling in mammalian retina: results from studies of experimental retinal detachment. Prog Ret Eye Res 24:395-431. CrossRef Medline

Fox K, Wong RO (2005) A comparison of experience-dependent plasticity in the visual and somatosensory systems. Neuron 48:465-477. CrossRef Medline

Frotscher M, Zhao S, Förster E (2007) Development of cell and fiber layers in the dentate gyrus. Prog Brain Res 163:133-142. CrossRef Medline

Fuerst PG, Bruce F, Tian M, Wei W, Elstrott J, Feller MB, Erskine L, Singer JH, Burgess RW (2009) DSCAM and DSCAML1 function in self-avoidance in multiple cell types in the developing mouse retina. Neuron 64:484497. CrossRef Medline

Haeseleer F, Imanishi Y, Maeda T, Possin DE, Maeda A, Lee A, Rieke F, Palczewski K (2004) Essential role of $\mathrm{Ca}^{2+}$-binding protein 4, a Cav1.4 channel regulator, in photoreceptor synaptic function. Nat Neurosci 7:1079-1087. CrossRef Medline

Haverkamp S, Grünert U, Wässle H (2001) The synaptic architecture of AMPA receptors at the cone pedicle of the primate retina. J Neurosci 21:2488-2500.

Huang L, Max M, Margolskee RF, Su H, Masland RH, Euler T (2003) G protein subunit $\mathrm{G}$ gamma 13 is coexpressed with $\mathrm{G}$ alpha $\mathrm{o}$, $\mathrm{G}$ beta 3 , and G beta 4 in retinal ON bipolar cells. J Comp Neurol 455:1-10. CrossRef Medline

Huberman AD, Clandinin TR, Baier H (2010) Molecular and cellular mechanisms of lamina-specific axon targeting. Cold Spring Harb Perspect Biol 2:a001743. CrossRef Medline

Huckfeldt RM, Schubert T, Morgan JL, Godinho L, Di Cristo G, Huang ZJ, Wong RO (2009) Transient neurites of retinal horizontal cells exhibit columnar tiling via homotypic interactions. Nat Neurosci 12:35-43. CrossRef Medline

Keeley PW, Reese BE (2010) Role of afferents in the differentiation of bipolar cells in the mouse retina. J Neurosci 30:1677-1685. CrossRef Medline

Keeley PW, Sliff BJ, Lee SC, Fuerst PG, Burgess RW, Eglen SJ, Reese BE (2012) Neuronal clustering and fasciculation phenotype in Dscam- and Bax-deficient mouse retinas. J Comp Neurol 520:1349-1364. CrossRef Medline

Kremer JR, Mastronarde DN, McIntosh RJ (1996) Computer visualization of three-dimensional image data using iMod. J Struct Biol 116:71-76. CrossRef Medline

Kwan KM, Behringer RR (2002) Conditional inactivation of Lim1 function. Genesis 32:118-120. CrossRef Medline

Lee SC, Cowgill EJ, Al-Nabulsi A, Quinn EJ, Evans SM, Reese BE (2011) Homotypic regulation of neuronal morphology and connectivity in the mouse retina. J Neurosci 31:14126-14133. CrossRef Medline
Lewis GP, Linberg KA, Fisher SK (1998) Neurite outgrowth from bipolar and horizontal cells after experimental retinal detachment. Invest Ophthalmol Vis Sci 39:424-434. Medline

Liets LC, Eliasieh K, van der List DA, Chalupa LM (2006) Dendrites of rod bipolar cells sprout in normal aging retina. Proc Natl Acad Sci U S A 103:12156-12160. CrossRef Medline

Mansergh F, Orton NC, Vessey JP, Lalonde MR, Stell WK, Tremblay F, Barnes S, Rancourt DE, Bech-Hansen NT (2005) Mutation of the calcium channel gene Cacnalf disrupts calcium signaling, synaptic transmission and cellular organization in mouse retina. Hum Mol Genet 14:30353046. CrossRef Medline

Marc RE, Jones BW, Watt CB, Strettoi E (2003) Neural remodeling in retinal degeneration. Prog Ret Eye Res 22:607-655. CrossRef Medline

Matsuoka RL, Chivatakarn O, Badea TC, Samuels IS, Cahill H, Katayama K, Kumar SR, Suto F, Chédotal A, Peachey NS, Nathans J, Yoshida Y, Giger RJ, Kolodkin AL (2011a) Class 5 transmembrane semaphorins control selective Mammalian retinal lamination and function. Neuron 71:460-473. CrossRef Medline

Matsuoka RL, Nguyen-Ba-Charvet KT, Parray A, Badea TC, Chédotal A, Kolodkin AL (2011b) Transmembrane semaphorin signalling controls laminar stratification in the mammalian retina. Nature 470:259-263. CrossRef Medline

Matsuoka RL, Jiang Z, Samuels IS, Nguyen-Ba-Charvet KT, Sun LO, Peachey NS, Chédotal A, Yau KW, Kolodkin AL (2012) Guidancecue control of horizontal cell morphology, lamination, and synapse formation in the mammalian outer retina. J Neurosci 32:6859-6868. CrossRef Medline

Mears AJ, Kondo M, Swain PK, Takada Y, Bush RA, Saunders TL, Sieving PA, Swaroop A (2001) Nrl is required for rod photoreceptor development. Nat Genet 29:447-452. CrossRef Medline

Morgan JL, Dhingra A, Vardi N, Wong RO (2006) Axons and dendrites originate from neuroepithelial-like processes of retinal bipolar cells. Nat Neurosci 9:85-92. CrossRef Medline

Poché RA, Kwan KM, Raven MA, Furuta Y, Reese BE, Behringer RR (2007) Lim1 is essential for the correct laminar positioning of retinal horizontal cells. J Neurosci 27:14099-14107. CrossRef Medline

Poché RA, Raven MA, Kwan KM, Furuta Y, Behringer RR, Reese BE (2008) Somal positioning and dendritic growth of horizontal cells are regulated by interactions with homotypic neighbors. Eur J Neurosci 27:1607-1614. CrossRef Medline

Raisman G (1994) Plasticity of adult central fibre tracts. Prog Brain Res 100:195-201. CrossRef Medline

Raven MA, Stagg SB, Nassar H, Reese BE (2005) Developmental improvement in the regularity and packing of mouse horizontal cells: implications for mechanisms underlying mosaic pattern formation. Vis Neurosci 22: 569-573. CrossRef Medline

Raven MA, Orton NC, Nassar H, Williams GA, Stell WK, Jacobs GH, BechHansen NT, Reese BE (2008) Early afferent signaling in the outer plexiform layer regulates development of horizontal cell morphology. J Comp Neurol 506:745-758. CrossRef Medline

Reese BE, Raven MA, Stagg SB (2005) Afferents and homotypic neighbors regulate horizontal cell morphology, connectivity, and retinal coverage. J Neurosci 25:2167-2175. CrossRef Medline

Sanes JR, Yamagata M (2009) Many paths to synaptic specificity. Annu Rev Cell Dev Biol 25:161-195. CrossRef Medline

Schubert T, Huckfeldt RM, Parker E, Campbell JE, Wong RO (2010) Assembly of the outer retina in the absence of GABA synthesis in horizontal cells. Neural Dev 5:15. CrossRef Medline

Sherry DM, Wang MM, Bates J, Frishman LJ (2003) Expression of vesicular glutamate transporter 1 in the mouse retina reveals temporal ordering in development of rod vs. cone and ON vs. OFF circuits. J Comp Neurol 465:480-498. CrossRef Medline

Sonntag S, Dedek K, Dorgau B, Schultz K, Schmidt KF, Cimiotti K, Weiler R, Löwel S, Willecke K, Janssen-Bienhold U (2012) Ablation of retinal horizontal cells from adult mice leads to rod degeneration and remodeling in the outer retina. J Neurosci 32:10713-10724. CrossRef Medline

Sotelo C, Dusart I (2009) Intrinsic versus extrinsic determinants during the development of Purkinje cell dendrites. Neuroscience 162:589-600. CrossRef Medline

Soto F, Watkins KL, Johnson RE, Schottler F, Kerschensteiner D (2013) NGL-2 regulates pathway-specific neurite growth and lamination, syn- 
apse formation, and signal transmission in the retina. J Neurosci 33: 11949-11959. CrossRef Medline

Specht D, Tom Dieck S, Ammermüller J, Regus-Leidig H, Gundelfinger ED, Brandstätter JH (2007) Structural and functional remodeling in the retina of a mouse with a photoreceptor synaptopathy: plasticity in the rod and degeneration in the cone system. Eur J Neurosci 26:2506-2515. CrossRef Medline

Swindell EC, Bailey TJ, Loosli F, Liu C, Amaya-Manzanares F, Mahon KA, Wittbrodt J, Jamrich M (2006) Rx-Cre, a tool for inactivation of gene expression in the developing retina. Genesis 44:361-363. CrossRef Medline

Trevarrow B, Marks DL, Kimmel CB (1990) Organization of hindbrain segments in the zebrafish embryo. Neuron 4:669-679. CrossRef Medline

Wieloch T, Nikolich K (2006) Mechanisms of neural plasticity following brain injury. Curr Opin Neurobiol 16:258-264. CrossRef Medline
Wong RO, Ghosh A (2002) Activity-dependent regulation of dendritic growth and patterning. Nat Rev Neurosci 3:803-812. CrossRef Medline

Wu F, Li R, Umino Y, Kaczynski TJ, Sapkota D, Li S, Xiang M, Fliesler SJ, Sherry DM, Gannon M, Solessio E, Mu X (2013) Onecut1 is essential for horizontal cell genesis and retinal integrity. J Neurosci 33:13053-13065, 13065a. CrossRef Medline

Yamagata M, Sanes JR (2008) Dscam and Sidekick proteins direct laminaspecific synaptic connections in vertebrate retina. Nature 451:465-469. CrossRef Medline

Yamagata M, Sanes JR (2012) Expanding the Ig superfamily code for laminar specificity in retina: expression and role of contactins. J Neurosci 32:14402-14414. CrossRef Medline

Young RW (1985) Cell differentiation in the mouse retina. Anat Rec 212: 199-205. Medline 